Portland State University

PDXScholar

Fall 11-21-2014

\title{
Using Art to Teach Students Science Outdoors: How Creative Science Instruction Influences Observation, Question Formation, and Involvement
}

Christina Schull Cone

Portland State University

Follow this and additional works at: https://pdxscholar.library.pdx.edu/open_access_etds

Part of the Art Education Commons, and the Science and Mathematics Education Commons Let us know how access to this document benefits you.

\section{Recommended Citation}

Cone, Christina Schull, "Using Art to Teach Students Science Outdoors: How Creative Science Instruction Influences Observation, Question Formation, and Involvement" (2014). Dissertations and Theses. Paper 2098.

https://doi.org/10.15760/etd.2096

This Thesis is brought to you for free and open access. It has been accepted for inclusion in Dissertations and Theses by an authorized administrator of PDXScholar. Please contact us if we can make this document more accessible: pdxscholar@pdx.edu. 
Using Art to Teach Students Science Outdoors:

How Creative Science Instruction Influences

Observation, Question Formation, and Involvement

by

Christina Schull Cone

A thesis submitted in partial fulfillment of the requirements for the degree of

Master of Science Teaching

in

General Science

Thesis Committee:

William Becker, Chair

Melissa Potter

Stephanie Wagner

Portland State University

2014 


\begin{abstract}
Elementary education has become increasingly divided into subjects and focused on the demand for high math and reading scores. Consequently, teachers spend less time devoted to science and art instruction. However, teaching art and science is crucial to developing creative and rational thinking, especially for observation and questioning skills. In this study, third grade students attending an urban school in Portland, Oregon received instruction of an art strategy using observational and quantifying drawing techniques. This study examines, "Will an art strategy observing the local environment help students make observations and ask questions?" and "In what ways are student learning and perspectives of science affected by the art strategy?" The independent variable is the art strategy developed for this study. There are three dependent variables: quality of student observations, quality of questions, and themes on student learning and perspectives of science. I predicted students would develop strong observation and questioning skills and that students would find the strategy useful or have an increased interest in science. The art scores were high for relevance and detail, but not for text. There were significant correlations between art scores and questions. Interviews revealed three themes: observations create questions, drawing is helpful and challenging, and students connected to science. By examining science through art, students were engaged and created strong observations and questions. Teachers need to balance unstructured drawing time with scaffolding for optimal results. This study provides an integrated science and art strategy that teachers can use outdoors or adapt for the classroom.
\end{abstract}




\section{Acknowledgements}

I thank the students and staff at the Creative Science School

for their participation in the study and thoughtful work.

I thank my friends, family, and advisors

for their encouragement.

Most of all, I thank Paul and Ellie

for their support, patience, and love. 


\section{Table of Contents}

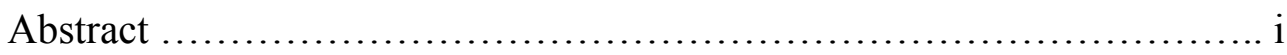

Acknowledgements ................................................

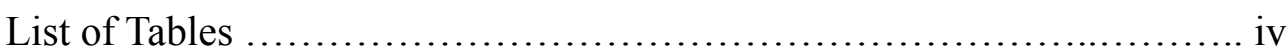

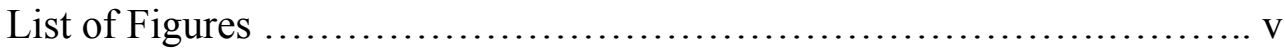

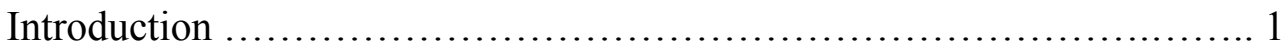

Literature Review ................................................ 5

Methods ............................................................... 19

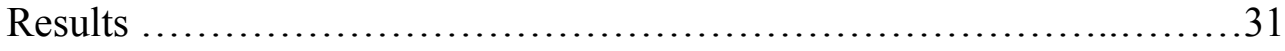

Discussion .................................................49

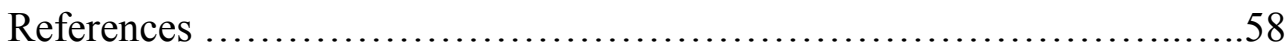

Appendices

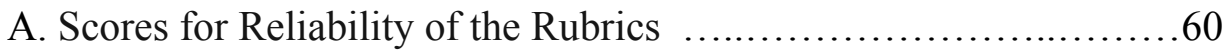

B. Internal Reliability Scores....................................61

C. Student Drawing and Question Scores...........................62

D. Coded Student Interview Data................................64 


\section{List of Tables}

Table 1. Description of Lessons Over Five Weeks.............................21

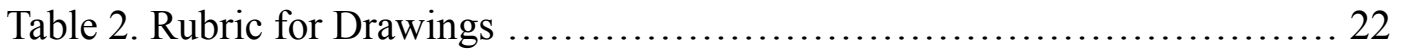

Table 3. Rubric for Questions ....................................... 23

Table 4. List of Student "I wonder" Questions with Scores.......................... 33 


\section{List of Figures}

Figure 1. Week Three Art Scores Correlate with Question Scores .................... 34

Figure 2. Week Three Detail Scores Correlate with Question Scores .................35

Figure 3. Median Score for Relevance, Detail, and Text .......................... 35

Figure 4. Mean Score for Relevance, Detail, and Text ............................36

Figure 5. Student 14's painting from week five. ............................... 38

Figure 6. Student 1 wondered "How 7 leafs can fit in 1 leaf" during lesson four ...... 40

Figure 7. Student 2 said his question just came to him during lesson four .............41

Figure 8 . Student 5 said that even painting helps her notice ......................42

Figure 9. Student 6 connects to the drawing aspect of the lesson during week one.....43

Figure 10. Student 21 said she had difficulty making size comparisons for lesson two. 44

Figure 11. Student 12 recalls her curiosity from the first lesson................... 45

Figure 12. Student 13 thinks about bees and raspberry flowers during lesson three .... 47

Figure 13. Student 20 said the lessons were fun and she learned more about science... 48 


\section{Introduction}

This study aimed to develop an art tool utilizing observation and question formation that teachers can use to engage and direct science learning in an outdoor setting. Oftentimes, art and science are viewed as independent disciplines in the school system. In careers like graphic design, engineering, biology, and geography, artistic and scientific thinking processes are interwoven. An understanding of how creative and logical thinking overlap is crucial to a growing society. Integrating non-linear thinking will help develop creative science problem solvers of the future.

In Oregon, as in other states, reading, writing and math have been the focus of elementary basic skills testing. Generally speaking, art and science instruction usually suffer from funding cuts before instruction of reading and math. However, communities in Oregon are recognizing the importance of art, science, and outdoor education. There is a bottom up approach that art is essential to student learning. In 2012, Portland voters passed a new tax to support art funding in schools (City of Portland, 2014). Science education is being re-examined in Oregon, too. The 2013 Next Generation Science Standards were adapted by Oregon to increase science learning by focusing on specific content, practices, and core ideas (NGSS 2014). Overall, local and national communities are supporting a strong need for art and science education.

Oregon has also increased its call for outdoor education over the last ten years through the No Child Left Inside movement. This movement aims to increase outdoor and sustainability education in our public schools. One result of the movement is the 
Oregon Environmental Literacy Plan, which describes the importance of creating regular outdoor experiences for school and how to implement environmental literacy. House Bill 2544, signed into law in 2009, declares the need for environmental education an emergency (OR DOE). In Oregon, outdoor instruction is now backed up by legislation.

Outdoor education is not new to the education field. One proponent of interdisciplinary thinking, Howard Gardner, wrote up a preliminary description of several "multiple intelligences" in 1983. Gardner identified five core intelligences that people possess to varying degrees. In the late 1990s, he began reassessing the list, and he added naturalist intelligence to include the ability to recognize and connect with plants, animals, and outdoor phenomenon (Gardner, 1999).

The tool used to teach children science in this study combined three of Gardner's intelligences: spatial/pattern/artistic, logical/mathematical, and naturalistic. Conducting scientific inquiry outdoors touched upon naturalistic intelligence. Drawings that required students to observe overall patterns and spatial relationships connected with artistic intelligence. Mathematical intelligence was touched upon when students were instructed in finding quantifiable relationships among natural objects and settings. My instruction of art throughout an outdoor science inquiry experience has the potential to expand student thinking and understanding and to encourage interdisciplinary problem solving.

Some educators have worked to integrate the arts and sciences in different ways. In the literature, there is evidence of successes using outdoor education and studies where art and science have been explored simultaneously. Outdoor education provides real-life 
problem solving, connects students to their community, and increases scores. Researchers have found that outdoor education increases understanding of science content. By adding outdoor science experiences, teachers can add to students' ecological literacy and increase meaning, cognition, and affect.

While studies of integrated education exist, the literature is limited in integrated art and science experiences. One researcher found that integrating science with art allowed for problem solving, critical thinking, and reflection. In another study, researchers found that art in an outdoor setting allows students to develop deeper observational skills, link to science, and feel connected to their experiences. The literature adds to the argument that using art to teach science outdoors may increase student's observation, thinking skills, and motivation. However, many education studies examine integration on a superficial level versus how the practices of art and science directly overlap. My study takes the art science experience a step further in using a method to stimulate observation skills and generate "I wonder" questions.

My study is a mixed-methods case study utilizing qualitative interviews analyzed for themes, and student work samples scored using a rubric. The study was implemented in one third grade classroom. The research questions are: "Will an art strategy observing the local environment help students to make observations and ask questions?" and "In what ways are student learning and perspectives of science affected by the art strategy?" The independent variable is the art strategy of outdoor instruction that was developed for this study. There are three dependent variables in this study: the quality of student 
observations, the quality of formulated questions, and student learning outcomes and perceptions of the strategy. I predicted the art strategy would help engage students, particularly those who are artistic or visual learners. I also predicted students would make strong observations and develop deeper scientific questions. Finally, I anticipated that the strategy would engage students through integrating the similar practices used within art and science. 


\section{Literature Review}

I present literature that begins with the big picture and then becomes more specific as it relates to my study. I introduce the literature by presenting how art and science are similar. I then review how art can help students to make strong observations. Next, I examine how good observations can lead to good questions and why strategies are needed to help kids to ask questions. Then, I discuss how good questioning is important for science. Finally, I summarize the literature, make connections amongst the studies, and illustrate how it connects to my research. The following literature makes a case for practicing creative science outdoors.

Art and Science are Similar

Science education has traditionally been based on making observations and trying to answer questions, either through experiments indoors or outdoors within the natural sciences. Art is often an indoor pursuit though many artists work outdoors. The products of art and science are different, though the practices within each are very similar. This theory provides justification to pursue artistic and scientific practices side-by-side and to provide a thorough exploration of the world through creative-rational lenses. Berstein and Berstein (2004) describe scientific-artists and artistic scientists, claiming that both artists and scientists use the following interactive thinking skills:

$\begin{array}{llll}\text { Observing } & \text { Pattern Recognizing } & \text { Empathizing } & \text { Playing } \\ \text { Imagining } & \text { Pattern Forming } & \text { Body Thinking } & \text { Transforming } \\ \text { Abstracting } & \text { Analogizing } & \text { Modeling } & \text { Synthesizing }\end{array}$


Observing involves activating all the senses and takes patience. In imagining, an artist or scientist uses all his or her senses to recall observations and then create imaginary worlds. Through abstracting, people focus on one main idea or part of a larger picture. And in pattern recognizing, someone organizes what they observe, often intuitively. While creative scientists and artists may not necessarily think with the same symbols and vocabulary that they express their ideas with, they use the same thinking processes. Their thinking may also include how they feel, which is often described as intuition. This creative impulse can fuel both artistic and scientific thought and allows for connectivity amongst differing ideas (Berstein \& Berstein 2004).

The elementary art and science standards also pose crossover between disciplines. Since the participants were in grade three, I examined grade three art and science standards to define the practices of art and science for this study. When possible, I tied the art lessons into lesson content, which reflect standards, taught by the primary teacher. For example, I connected one lesson with pollinators from their science unit and another with proportion comparisons since the students were studying fractions in math. I was able to find overlapping terms in the standards for grade three art and science.

The standards I examined can be adapted to tie in with specific lesson content or to include more science and art specific standards, especially in regards to how students are asked to convey and present information. I have listed the third grade Oregon art and science standards that the art strategy addressed below. The science standards come from the Next Generation Science Standards. I bolded significant terms and italicized words 
that could be used to describe both art and science practices to emphasize that both disciplines develop higher-order thinking skills. The art strategy addressed the following art standards for grade three regarding creating, presenting, and analyzing:

AR.03.CP.01 Use experiences, imagination, essential elements and organizational principles to achieve a desired effect when creating, presenting and/or performing works of art. (Content Standard: Use essential elements and organizational principles to create, present and/or perform works of art for a variety of purposes.)

AR.03.CP.02 Explore aspects of the creative process and the effect of different choices on one's work. (Content Standard: Explore and describe the use of ideas, techniques, and problem solving in the creative process (e.g., planning, choice of medium, choice of tools, analysis and revision) and identify the impact of choices made.)

AR.03.CP.03 Create, present and/or perform a work of art that demonstrates an idea, mood or feeling. (Content Standard: Create, present and/or perform a work of art that demonstrates an idea, mood or feeling by using essential elements and organizational principles, and describe how well the work expresses one's intent.)

AR.03.CP.04 Describe how one's own work reveals knowledge of the arts, orally and in writing. (Content Standard: Critique and communicate about one's own work, orally and in writing.)

Similar to the art standards listed above, the activity addressed the science standards regarding scientific question formation. These standards were released in 2014 as the Next Generation Science Standards. The new standards focus on seven key practices in addition to core content and cross-cutting concepts. In my study, the focus was on Practice 1: Asking Questions and Defining Problems, though observational drawing could also lead into Practice 2: Developing and Using Models or many other practices with guided instruction. The current third grade science standards relating to asking scientific observations and questions are described below: 
3-PS2-1. Plan and conduct an investigation to provide evidence of the effects of balanced and unbalanced forces on the motion of an object.

3-PS2-2. Make observations and/or measurements of an object's motion to provide evidence that a pattern can be used to predict future motion.

3-PS2-3. Ask questions that can be investigated based on patterns such as cause and effect relationships.

3-LS1-1. Develop models to describe that organisms have unique and diverse life cycles but all have in common birth, growth, reproduction, and death.

3-LS3-1. Analyze and interpret data to provide evidence that plants and animals have traits inherited from parents and that variation of these traits exists in a group of similar organisms.

3-5-ETS1-1. Define a simple design problem that can be solved through the development of an object, tool, process, or system and includes several criteria for success and constraints on materials, time, or cost.

The lists above target specific art and science standards. However, the goal of the art strategy is not to increase divergent or subject-based thinking. The goal of this strategy is to increase awareness on how disciplines intersect and that the practice of art and science require similar creative and reasoning abilities. The bolded and italicized terms in the lists above include overlapping art and science terms such as "plan, create/ conduct/develop, describe, and problem solving." Both art and science ask students to make observations and describe their sensory experience, plan their work, create or develop a product or idea, and solve problems. Art and science often require students to analyze and ask questions, interpret and find patterns, and quantify observations. Practicing art and science together will help students develop sophisticated thinking skills for approaching questions that may arise in any discipline. 


\section{Art Can Lead to Good Observations}

Art is important for science and for making observations. Art can teach skills like the patience needed for observation, techniques for drawing, and how to record what we see. Hillary Inwood, a Canadian researcher, provides a comprehensive study of the role of outdoor art education in developing ecological literacy. Inwood conducted action research on the implementation of eco-art curricula in four Canadian schools. One of the questions that arrived from this study, that would be beneficial to the broader literature is,

"What is the nature of students' experience, and does eco-art learning have a long-lasting impact on their environmental literacy and eco-friendly behaviors?" (Inwood 2009). One of Inwood's goals was to use art in ecological education to go beyond stating facts to conveying meaning of ecological topics. She argues that the process of making art can be a means to "create new knowledge and understanding." Inwood argues that eco-art education supports both art and environmental learning. One teacher in her study noted she believed that appealing to naturalist intelligence allowed students who usually had difficulty with traditional learning to be successful at school. Teachers implemented many local eco-art projects from murals to interdisciplinary lessons with science, and assessed the results. Some of the projects involved school gardens while others involved observing nature or using natural found objects in creating art. The benefits of focusing on art education include engaging students in creative problem-solving, critical thinking, and self-reflection (Inwood 2009). By combining art education learning outcomes with science, teachers can enhance science learning, literacy, and observation. 
There are other studies that explore the role of art in making observations and understanding our world. Trimis and Savva (2009) propose that examining the environment through objects and materials in that place allows students to view themselves as part of the place. According to the authors, scientists and educators "have agreed that the mind creates knowledge in response to the world as it creates and recreates itself." In this way, the process of creating is not only an artistic process, but a human endeavor of innovation and coming to understanding of the world around us.

Trimis and Savva (2009) further claim that artistic activities engage emotions, and that exploration of local settings allows students to connect to their natural or man-made environment. In their study, the authors examined using the natural and built environment of schools, allowing students to explore materials and space, exercise all the senses, make observations, explore, analyze, and partake in meaningful experiences. Art was used to explore ecological, social, or cultural aspects of a place, and the influence of environment on the students. Students from three classes were engaged in open-ended inquiry and exploration of materials, enrichment of experience through revisiting man-made and natural environments, the production of art, and reflection and communication. All the teachers said they could easily link creating with observing art. Visual experiences were linked with environmental education, science, and spatial concepts. For example, students' observations and questions that resulted from one experience included, "These pinecones are huge and these are so small... Why?" and, "This looks like a sunflower. It is soft with some dark lines" (Trimis \& Savva 2009). The skills used for these types of 
artistic observations are the same skills used for science observation. The recognition of patterns, shapes, and innate properties of objects are at the beginning of both disciplines. Recognizing non-visible cues like smells, energy flow, and water cycles are at the next level of observation. In Trimis and Savva's (2009) study, teachers found that using local settings allowed deeper exploration, making it easier to link art with teaching other ideas like science, environmental education, and spatial concepts.

Finally, Karen Gallas (1991) explores art as a methodology for acquiring knowledge, also called teaching through the arts. She discusses how integrating arts can be helpful for English language learners, rather than using text alone. Art can also open the door into other domains as students use visual representations to organize science information and create science questions. Gallas argues that elementary aged students depend on play and creative endeavors as a way to understand their world; drawing can be used for observation and as a way to learn science through the arts. One of Gallas' classes discussed why they were sketching. One student said “I didn’t know what it was. So I looked at a book, and then I drew it, and then, then you know." His classmate responded, “Or if you don't know what a wing is and how it's made you can draw it and then you know." In this way, drawing is a way to explore and represent what we know about science. Drawing can be helpful for visual learners while also challenging students who are less visually included to share information and connect in new ways (Gallas 1991). 


\section{Good Observations Lead to Good Questioning}

While most kids are innately curious, students can struggle to ask questions, especially in the context of science. The literature supports the theory that students who take the time to make good observations are more likely to ask better questions. Eberbach and Crowley (2009) claim that observation can have different roles and that students asking questions originates from children's interests and observations of familiar living things. The authors state that question asking can occur after observation, which can be followed by new observations, resulting in a question and observation cycle. They note that expert observers use observation throughout the inquiry process versus everyday observers that use observation mainly to collect data. In this way, observations can lead to questioning, hypotheses, and testing (Eberbach and Crowley 2009).

Eberbach and Crowley (2009) claim that the way students observe and make inferences are not always scientific and that students can become great scientific observers given adequate support. The authors mention that "it is common knowledge" that children spontaneously make drawings, and students often don't want the responsibility of recording observations during scientific data collection. Educators need to teach students knowledge of scientific disciplines during observations and providing the supports and tools to make more scientific observations (Eberbach and Crowley 2009).

Eberbach and Crowley (2009) state that expert biologists may generate questions during data collection. They discuss how botanists make observations first, combine the 
information with prior knowledge, and then begin to make comparisons. These experts are making observations while simultaneously asking questions. The questions that experts come up with respond to the most important parts of what they notice. Finally, the authors talk about how seeing is not the same as observing and that scaffolding is needed to teach observation (Eberbach and Crowley 2009).

While making observations for stimulating question formation is important, the types and questions students ask and the strategies teachers use to prompt question formation is equally important. Chin and Brown (2002) studied the types of questions students ask during science lessons which include factual or procedural and deeper wonderment questions. They claim that most classrooms involve teachers asking students closed factual questions that have one answer. When a classroom is set up for studentgenerated questions, the teacher often focuses on questions based off of text materials rather than spontaneous questions generated from students trying to understand the world around them. When students are familiar with a topic, "wonderment questions" that reflect curiosity, disequilibrium, skepticism, and speculation are generated (Chin and Brown 2002).

Chin and Brown (2002) argue that by allowing students to generate their own questions, a teacher engages student curiosity and connects to subsequent scientific practices. Student questions can be used to guide investigations and acquisition of knowledge. In this study, they found that half of the student generated questions focused on explanations or understanding phenomena. "I wonder" questions were a small 
percentage of the total questions that students asked during hands-on activities (between 2 and 30 percent depending on the activity, average 14\%). The wonderment questions made students think more deeply, generating possible explanations to questions and solutions to problems. Students did not necessarily ask wonderment questions spontaneously, providing rationale that students need to be encouraged to ask questions or they might not ask them. The results of Chin and Brown's study show that teachers must explicitly aim towards getting their students to ask questions whether verbal or written. It is important for students to be able to generate their own questions in science. Students forming their own questions makes learning more meaningful, provides motivation, helps with reflection, and is necessary for problem solving (Chin and Brown 2002).

Chin and Brown (2002) claim that more research is needed on students asking their own questions, specifically practical and stimulating strategies that teachers can use to encourage student questioning. They mention that unstructured observations increase the amount of questions students ask. They also state that the practice of asking questions needs to be taught rather than assuming that students will ask questions. Teachers can have students record "I wonder" questions and then use the questions as the beginning for investigations (Chin and Brown 2002). 
Art observations that help students raise questions are crucial because asking good questions is an essential skill for science. The Next Generation Science Standards and K-12 Framework for Science Education identify "asking questions" as the first practice in science education. Students must also be able to collect empirical evidence such as observations to support arguments. The standards for grades K-2 require that students be able to "ask questions based on observations to find more information about the natural and/or designed world(s)." Through the standards for grades 3-5, students build on this by asking questions that can be investigated like patterns of cause and effect, what would happen if a variable is changed, and identifying scientific (testable) and nonscientific (non-testable) questions (NGSS 2012).

The first step of asking questions in the practice of science is so crucial because questions engage curiosity, drive meaningful learning, and influence motivation (Framework 2012). A full description of how science begins and how it unfolds is in the Framework:

Science begins with a question about a phenomenon, such as "Why is the sky blue?" or "What causes cancer?," and seeks to develop theories that can provide explanatory answers to such questions. A basic practice of the scientist is formulating empirically answerable questions about phenomena, establishing what is already known, and determining what questions have yet to be satisfactorily answered. 
Before a student can ask a question, she or he must notice a phenomenon. As stated above, the phenomenon can be something that can be answered through research or further investigation or experimentation. The question is the most important part of the study because it establishes what the student wants to know or learn and without that impetus, there would be know exploration. Question formation also allows students to reinvestigate new phenomena as they go through the science practices non-linearly. Students may come up with new questions as they undertake an experiment or collect and analyze data. These new questions help scientists to investigate a topic further. Overall, asking good questions is an essential part practicing science as this process lays the foundation for how to go about investigations.

\section{Summary}

A thorough view of the literature for this study includes work on how art and science are similar, how art can lead to good observations, how good observations lead to good questioning, and how good questioning is important for science. We need strategies to help students ask questions. To get students to ask questions, we must provide them with opportunities to find and interact with interesting material or phenomena. We must also make learning relevant to peek student motivation and interest in science by allowing students to ask questions about their environment. My strategy uses art in outdoor settings to make learning relevant and tap into students' natural curiosity of the world around them, in order to help students generate their own questions. 
The discussion of art and science similarities as presented by Berstein and Berstein, and how the beginning practices of each align, make a case for teaching integrated art and science lessons. Inwood claims that when art is used to teach ecology, it helps to create knowledge and understanding and to promote critical thinking and reflection. Trimis and Savva also claim that the process of creating in their environment allows students to observe and understand their surroundings. Gallas explains how drawing through the arts can help students to understand science content. Questions and observations from environmental art experiences allow students to explore deeper and make interdisciplinary connections.

Once students begin to make observations through art, they can formulate their scientific questions. Eberbach and Crowley discuss how observations lead to questions and how these processes sometimes occur simultaneously or in a cycle. Teachers need to provide adequate support and scaffolding for students as they create questions. Chin and Brown call for strategies to help students develop questioning abilities. They argue for the importance of wonderment questions and how crucial it is that students are able to ask and investigate their own questions. Furthermore, The Next Generation Science Standards call for students to be able to ask questions and identify investigative questions by third grade. Students need to know the importance of both researchable and investigative questions. The NGSS principles further state that "Science assumes that objects and events in natural systems occur in consistent patterns that are understandable through measurement and observation.” Therefore, my art lessons involving students in 
observation and measurement outdoors get at the heart of the science principles that students need to learn.

The literature suggests that there is a need for strategies to engage students in asking questions and that teaching science observation through the arts may be an avenue to accomplish this task. While the products of science and art are different, the processes of observation, knowing, and understanding are similar. My study documents a relatively new science teaching strategy. The intentional use of art in teaching science outdoors is meant to maximize student learning and engagement. Outcomes include not only demonstrating interdisciplinary ways of thinking and understanding, but also discovering how to use skills from different subject areas explicitly in observing, describing, and asking questions about about our surroundings. By using interdisciplinary strategies to connect to both creative and rational thinking, teachers can engage more students in science practices. In the following pages, I examine the extent that an art strategy, developed for the study, affected students' abilities to observe and form questions in an outdoor setting. I aimed to increase student motivation, participation, and connection to learning activities through the implementation of an art tool, and to engage students in generating scientific questions. 


\section{Methods}

\section{Overview}

The purpose of this study was to examine how an art strategy could be implemented outdoors to facilitate science understanding and the use of science practices. The study also aimed to explore how the art strategy impacts student motivation and connection to learning. The questions I explored were, "Will an art strategy observing the local environment help students to make observations and ask questions?" and "In what ways are student learning and perspectives of science affected by the art strategy?" I speculated that many students would benefit from using an art tool for learning because art provides a way to record and communicate thoughts and ideas. Art can engage students interested in art and those who learn well through visual or kinesthetic means. I was interested in exploring these questions because I believe making strong observations through art can help stimulate question formation, and the Next Generation Science Standards call for students to be able to generate and investigate questions about phenomenon. The literature also calls for strategies to help students ask questions.

The art strategy for this study was to incorporate drawing and painting into outdoor science instruction as a way to engage students in observing, noticing details, asking questions, and making relevant connections between what is being drawn on the page and what is observed. The strategy used was a series of five lessons where I presented material and topics to draw or paint and scaffolded how to focus on quality, quantity, interactions, description, and representation while making observations. 
This study used a quasi-experimental mixed methods case study design. During five weeks, the class received botany instruction from their primary teacher for about an hour a week as part of their science unit. I, working as the student teacher, conducted the art strategy outdoors for about an hour a week on three of the weeks and brought in local plant specimens for the remaining two weeks. After the study, I collected art work samples to score and analyze the student observations and questions. Some students were given interviews on their perceptions of science and the art strategy. The interview aimed to gather common themes regarding student interest in the activity, thoughts about observation and question formation, and connections between science and art (interdisciplinary thinking).

\section{Treatment}

To implement the treatment, I engaged students in an outdoor study of nature in an urban setting. The setting included the school garden, the school playing field, and the classroom (in which I brought objects from the neighborhood into the classroom). Students were instructed in observing, drawing, and quantifying natural objects and interactions related to botany in the environment because botany was the unit of science study during the five lessons (Table 1). I provided an example of how to draw observations and how to explore mathematical relationships within the observations, relying on exploration of details. Students were given the opportunity to pick their own "spot" to observe from. They were given between 30-45 minutes to complete their 
drawings on large paper (11" x 14"), with explicit instruction during some lessons to include at least one mathematical relationship or scientific question related to what was observed.

\section{Table 1. Description of Lessons Over Five Weeks}

1) First Draw (indoors): Draw using color, shape, size, texture, or sensory observations. Write one label or interesting thing about the plant. For example, write why you picked that plant or a question.

2) Size Comparisons (outdoors): Make size or proportion comparisons between two botany related objects. Label or write down the number comparison of objects.

3) Pollinator Interactions (outdoors): Draw pollinator interactions. Write down an "I wonder" question about their plant/animal interaction.

4) Leaf Draw (indoors): Take turns describing a leaf to your partner while the other person draws the "mystery" leaf. At the end of the lesson, write down an "I wonder" question.

5) Color Observation (outdoors): Paint or color a picture of a plant you observe.

\section{Instruments}

Student artwork. The student's art pieces were the measurement for evaluating student understanding. Two rubrics, created for this study, were used to score student observations and questions separately. There is one rubric for the student questions and one rubric for the observational drawings. I created the observation rubric by first distinguishing three criteria for strong observations: relevance, detail, and text (Table 2). Trowbridge and Wandersee (2005) recommend that rubric criteria include using details and comparisons through words that label, describe, interpret and explain. They also suggest observation rubrics focus on quality and quantity of the phenomenon being 
observed. I chose to base my rubric criteria for student observations on details, overall relevance to the lesson, and the quality and quantity of text.

\begin{tabular}{|l|c|l|l|l|l|}
\hline \multicolumn{1}{|l|}{ Table 2. Rubric for Drawings } \\
\hline Criteria & 0 & \multicolumn{1}{|c|}{1} & \multicolumn{1}{|c|}{2} & \multicolumn{1}{c|}{3} & \multicolumn{1}{c|}{4} \\
\hline Relevance & none & $\begin{array}{l}\text { Observations are } \\
\text { mostly unrelated } \\
\text { to the lesson* of } \\
\text { the day. }\end{array}$ & $\begin{array}{l}\text { Observations } \\
\text { have some } \\
\text { relevance to the } \\
\text { lesson*. }\end{array}$ & $\begin{array}{l}\text { Observations are } \\
\text { mostly relevant } \\
\text { to the lesson*. }\end{array}$ & $\begin{array}{l}\text { All observations } \\
\text { are relevant to } \\
\text { the lesson*. }\end{array}$ \\
\hline Detail & none & $\begin{array}{l}\text { Observations } \\
\text { have little detail. }\end{array}$ & $\begin{array}{l}\text { Observations } \\
\text { include 1-2 } \\
\text { details. }\end{array}$ & $\begin{array}{l}\text { Observations } \\
\text { have 3-4 details. }\end{array}$ & $\begin{array}{l}\text { Observations } \\
\text { have 5+ details. }\end{array}$ \\
\hline Text & none & $\begin{array}{l}\text { Words are } \\
\text { present but not } \\
\text { related to lesson } \\
\text { content. }\end{array}$ & $\begin{array}{l}\text { Words are } \\
\text { present with at } \\
\text { least one label or } \\
\text { other relevant } \\
\text { marker. }\end{array}$ & $\begin{array}{l}\text { 2-3 labels or } \\
\text { relevant markers } \\
\text { are present. }\end{array}$ & $\begin{array}{l}\text { 4 or more labels } \\
\text { or relevant } \\
\text { markers are } \\
\text { present. }\end{array}$ \\
\hline
\end{tabular}

*Lessons outlined in Table 1 .

I created the rubric for student questions along with one other science education professional. The rubric accounts for four types of questions: unrelated, affective, research, and investigative (Table 3). The criteria for each type of question ranged from questions not relevant to the lesson or of the affective domain, to questions that could be found out by researching it or asking a professional, and finally to questions that could be investigated by the student. 
Table 3. Rubric for Questions

\begin{tabular}{|c|c|}
\hline Score & Description \\
\hline $\mathbf{0}$ & none (no question written) \\
\hline 1 & Question is incomplete or unrelated to lesson content. \\
\hline 2 & Affective question related to how one feels about the lesson. \\
\hline 3 & $\begin{array}{l}\text { Research question that can be answered by asking an expert, reading literature, or } \\
\text { searching books or the internet. }\end{array}$ \\
\hline 4 & $\begin{array}{l}\text { Investigative question that can be answered by further observation, measuring, or } \\
\text { experimenting over time. }\end{array}$ \\
\hline
\end{tabular}

To increase the validity of the rubric, the student teacher and one other viewer scored eight pieces of student artwork for detail, relevance, and text. We also scored nine questions. We then cross-checked the scores to make sure that they were similar enough to validate the rubric.

Interviews. After implementing the art strategy over five weeks, nine students were interviewed about how the art strategy impacted their understanding and interests. I asked the students who chose to participate in interviews five questions, and I used follow-up questions to have students clarify their ideas. Each interview was approximately 5-8 minutes long, and none lasted longer than 10 minutes. The interview questions established a deeper understanding of how the students viewed the art-science experience. I began each interview by laying out all the drawings of the student being interviewed and asking the student to tell me a little bit about her or his work. The interview included the following questions: 
1. How did you come up with your "I wonder" questions?

2. When you drew or painted, how did it affect the way you saw things?

3. Did creating drawings or paintings affect the way you think about science?

4. Did you use any of the drawing or question strategies in any other classes?

5. If you were going to teach this class, how would you do it differently?

Before interviewing the students, these questions were shared with other

educators and checked for reliability in how the questions would assess student learning and understanding.

\section{Participants}

Participants were students from a third grade class at a public school in Portland,

Oregon. The school embraces science and places an emphasis on engaging curiosity and developing scientific questions. Of the nearly 400 students enrolled, 37\% qualify for free or reduced lunch, 3\% are English language learners, and about $80 \%$ of the students are white. This compares to the general Portland Public Schools District population which is $45 \%$ free or reduced lunch, $8 \%$ English language learners, and 56\% white (Portland Public Schools 2013). The class participating in this study was made up of 30 students. The class received the art lesson treatment during five weeks that the students were also receiving botany lessons as their science unit. The class was selected to receive the treatment because it is the class that I was assigned for a practicum experience, not due to favoring a certain group of students over another. All of the student work samples from the students that gave permission to include their work in the study (total of 20) were scored using a rubric. Nine students from the class chose and had time to participate in 
interviews (one student was completing other assignments). Only students who had given consent were included in the study. The students' work samples were assessed using a rubric, and the interviews were assessed for main themes.

\section{Treatment and Analysis}

During the course of the study, I focused on plant observations because botany was the science unit. The primary teacher provided the whole class with science instruction that included worksheets, a field trip, and dissection of flowers and fruit. I used the art strategy to explore science material with the class over the course of five weeks. I intentionally focused on botany and pollinators for content, a study of proportion because the students were learning about fractions, a partner study to engage students in peer discussion, and a final painting study with the basic instruction to observe plants (Table 1).

Each piece of artwork was numbered and randomly sorted by another person to take away bias of expected outcomes of individual student work and progression of individual work throughout the treatment. I scored the artwork and student questions using the rubrics I created (Tables 2 and 3). The criteria for the rubrics were finalized after I checked the criteria with another science education researcher for effectiveness. We then cross-checked our scores of both the questions and the art work samples to ensure reliability of the rubric (Appendix A). The criteria assessed each student's ability to make detailed and relevant observations with relevant text. The criteria for the question 
rubric assessed quality of the student questions. To ensure internal reliability of the rubric scores, I scored the same five papers three times, once at the beginning, middle, and end of scoring. My scores were mostly the same and within one point of each other except for two cases where the score changed two points (Appendix B).

Once the artwork samples were scored, an outside statistician assisted in analyzing the rubric for two main factors. For weeks three and four, the question score for each student was compared with the average of all three of his or her observation scores. The goal of this analysis was to see if there is a relationship between students' scores on their questions and scores on their art. We then checked to see if there was a relationship between detail of drawings and student questions for weeks three and four.

For the interviews, I used qualitative analysis as presented by Creswell (2013) to organize, code, create themes, interpret the data, and present the data. Instead of transcribing and reading through text, I first listened to the interviews three to four times and jotted down notes or specific quotes. Then, I formed a seven-code system based on recurring statements or ideas. The codes were then put together to form three common themes. The themes that emerged were compared with the work samples results for similar trends. 


\section{Day-by-Day Strategy}

The unit for the duration of the study focused on botany and the art strategy was linked to making observations in the natural environment when possible. The students received the treatment for approximately one hour per week for five weeks. The tenminute interviews were conducted outside of instruction time at the end of the five weeks.

On day one, I brought in about a dozen different types of live and dried plant samples from home (flowering grasses, eucalyptus, hens and chicks, daffodils with seed pods, pine cones, and other plants). Each students was allowed to choose one object to take back to his or her desk to draw. Students were prompted to notice what they saw, smelled, felt, and heard, while observing for about one minute. I reminded students that whatever they chose to notice and observe was valid. I demonstrated looking at an object as a whole, in this case the oval shape of a pinecone. I then asked students to examine one smaller aspect of their object and demonstrated noticing details about an object, in this case drawing the individual bracts of a pinecone. When students appeared to be less engaged or stuck, I prompted them with questions such as, "What else do you notice?" I asked students to observe color, size, texture, form, and shape of their chosen plant. On this first day, the students had about an hour total for the lesson, including about half an hour of drawing time. Some kids drew more than one object. Some students asked if they could take a plant home, which was allowed. 
One week later, I took the students to a grassy area outside the school for their second lesson. The students were asked to find a comfortable place to sit where they could observe a plant or animal within the landscape. I demonstrated observing a tree asking the students to examine the size, bark, branches, and leaves. I asked students to notice if there were any other plants or animals growing alongside the tree. There was some discussion as to whether the tree immediately next to the one being observed was part of the first tree or its own tree. I asked students to compare another tree (that was closer to the group and more obviously a separate tree) by noticing the differences between the two. I asked questions like, "What do you notice about this tree?," "What is similar in the two trees?," and, "What is different?" I demonstrated how to observe, draw, and label differences between two objects in the landscape.

During this second lesson, I explicitly engaged students in quantifying their observations. I exhibited the process of observing, making proportional measurement estimates, and recording observations through drawing. I held out my arm at a distance to use my fingers to measure the height of one of the trees. Holding my fingers the same distance apart, I measured how high the second tree was proportionally to the first. One tree was about ten times taller than the other. By demonstrating how to observe and draw quantifiable relationships, I engaged students in active observation of their environment. Later on I noticed that some students made the proportional size comparisons while others made more exact measurements in inches or feet. 
On the third day, I prompted students in an observational drawing of pollinator interactions outdoors. Students were studying pollinators with their primary teacher during the week. During my lesson, students were asked to write down an "I wonder" question about their observations. I asked students to help me explain what an "interaction" is. I then provided examples of interactions I was beginning to wonder about based on my immediate observations. After students made observations and "I wonder" questions, we sat down on the grass to share their drawings, findings, and inquiries at the primary teacher's request. This lesson was meant to promote learning to form questions, a crucial practice in both artistic representation and scientific inquiry. Sharing observations and questions can also be beneficial for peer learning.

On the fourth day, students continued to make observational drawings, this time through a partner activity. I brought in about a dozen different types of tree leaves, including conifer and broadleaf specimens. The kids found partners and took turns with one partner "hiding" their leaf and describing it to his or her partner to draw. The person describing was making the direct observation while the person drawing tried to interpret and create what their partner explained. The students switched on and off taking turns with different leaves. At the end, we had a short discussion of what the process was like, with many students saying it was hard to draw exactly what their partner described, or that they heard what their partner said but imagined it differently. At the end, students were asked to write an "I wonder" question on their pages. This lesson was meant to engage students in discussion, since elementary age students are going through a 
significant social development phase, and to engage English language learners who can benefit from practicing speaking and listening to descriptive language.

On the fifth day, I gave the students paint, crayons, and pastels to take outside in the garden. I did not provide much instruction other than asking the students to use their chosen materials to observe and represent something plant related. The purpose of this lesson was to allow students to further explore new or previous topics in a new art medium, provide an open forum for scientific exploration, and to see if students would use previously taught labeling and questioning techniques on their own.

Throughout instruction, I emphasized that the goal of creating observational drawings is not to make photogenic representations. Hence, accuracy was not a criteria for the drawings. The goal was to qualify and quantify what was seen through drawing and to recognize less overt details and relationships within the environment. I hoped to engage students full artistic creativity by providing students with large paper (11" x 17'), cardboard drawing boards, and pencils. On the first and last day they had the opportunity to use color either through colored pencils, pastels, crayons, or paint. 


\section{Results}

Traditionally, science questions have been presented by the teacher or have been generated through kits or experiments that have only one outcome. Science standards call for students to be able to ask questions and getting students to come up with their own questions to research or investigate can be a challenging task. In this study, I explored whether an art strategy helped students to make observations and ask questions. I also looked at how students perceptions were affected by the use of the strategy. The observations and questions were scored using rubrics and student perceptions were assessed through interviewing students and extracting themes from statements. The following pages present the results of question one (data on student scores) in the first section and question two (interview data) in the second section. All the student art and question scores are presented in Appendix C.

\section{Research Question 1: Will an art strategy observing the local environment help students to make observations and ask questions?}

Student artwork samples were scored according to relevance, detail, and text. Student artwork was overwhelmingly relevant to the lesson, with the average ranging between 3.6 and 4.0 for each week. Averages of weekly detail scores ranged from 2.9-3.8, and averages of weekly text scores ranged from 0-2.8. Student artwork resulted in observations that had very high relevance scores, high detail scores, and low to medium text scores. 
Students produced primarily researchable questions with two students, or $10 \%$ of the group, coming up with questions that could be investigated each week. Students produced more researchable questions during week three $(77 \%)$ than during week four (47\%). Two students scored 0-2 during week three, whereas six students scored 0-2 during week four. Overall, between $68-88 \%$ of the students that were present produced researchable or investigative questions for the weeks that they were asked to write down "I wonder" questions.

All of the student "I wonder" questions and their corresponding scores are listed below (Table 4). For week three, fourteen students made questions that deal mostly with why bees choose certain flowers, bee appearance or anatomy, and general bee behavior, which resulted in a question score of 3 for questions that can be researched. Two students received a score of 4 for asking an investigative question of how many pollinators they would notice. One student asked the affective question of whether the bee liked him. One student did not write any question (though he did create drawings) and two students were absent that day.

For week four, two students received a score of 4 for questions that can be investigated through measurement. These students were different individuals than the two students that received a score of 4 during the previous week. Eight students scored 3 for questions that can be researched. Two students scored 1 for either an unfinished question or a question unrelated to the lesson. Three students did not write down any questions and three students were absent. Two students scored 2 for affective questions. 


\section{Table 4. List of Student "I wonder" Questions* with Scores}

\begin{tabular}{|c|c|c|c|c|}
\hline Student & First question (pollinators) & score & Second question (leaves) & score \\
\hline 2 & $\begin{array}{l}\text { I wonder how mene pelenatrs I will } \\
\text { nodes }\end{array}$ & 4 & I wonder wye the led was so spike. & 3 \\
\hline 22 & I wonder why bees like nectar & 3 & $\begin{array}{l}\text { I wonder why we are so bad at drawing } \\
\text { Joe's home }\end{array}$ & 1 \\
\hline 28 & I wonder... if the Bee likes me! & 2 & I wonder if I drue these things & 2 \\
\hline 18 & I wounder why bees are so stripy? & 3 & $\begin{array}{l}\text { I wonder why this plant has a lot of } \\
\text { holes? }\end{array}$ & 3 \\
\hline 13 & $\begin{array}{l}\text { I wonder that why the bee land on } \\
\text { the raspberry flower? }\end{array}$ & 3 & I wonder that why it have spikes & 3 \\
\hline 21 & [none provided] & 0 & I wonder wye pine trees have needles? & 3 \\
\hline 12 & $\begin{array}{l}\text { I wonder why are Bees yellow and } \\
\text { blake? }\end{array}$ & 3 & I woneder why dose the pighn & 1 \\
\hline 5 & $\begin{array}{l}\text { I wonder how many pollinators I } \\
\text { will notice. }\end{array}$ & 4 & [none provided] & 0 \\
\hline 8 & $\begin{array}{l}\text { I wonder why bees do a eatern } \\
\text { (certain) pattinotre polinat. }\end{array}$ & 3 & $\begin{array}{l}\text { I wonder if why a seder tree is calde a } \\
\text { seeder tree? }\end{array}$ & 3 \\
\hline 14 & $\begin{array}{l}\text { I wonder why the bee choose this } \\
\text { flower to polenate? }\end{array}$ & 3 & I wonder why my partner chose this leaf. & 2 \\
\hline 3 & $\begin{array}{l}\text { I saw } 7 \text { bees. I wonderd if does not } \\
\text { like sertin flowers. }\end{array}$ & 3 & [absent] & $\mathrm{n} / \mathrm{a}$ \\
\hline 29 & $\begin{array}{l}\text { I wonder if bumblebees have } \\
\text { stinngers? }\end{array}$ & 3 & [none provided] & 0 \\
\hline 25 & I wonder how bees get polen. & 3 & $\begin{array}{l}\text { I wonder how many vans (veins) there } \\
\text { are? }\end{array}$ & 4 \\
\hline 6 & $\begin{array}{l}\text { I wonder why the bees like this } \\
\text { flower best. }\end{array}$ & 3 & $\begin{array}{l}\text { I wonder why some leaves are bigger } \\
\text { than others. }\end{array}$ & 3 \\
\hline 27 & [absent] & $\mathrm{n} / \mathrm{a}$ & I wounder... what the point is called. & 3 \\
\hline 30 & I wunder wiy its so small a be. & 3 & I wonder wit a pine has nietls! & 3 \\
\hline 7 & $\begin{array}{l}\text { I wonder why the pollen sticks to } \\
\text { the Bee's legs }\end{array}$ & 3 & [none provided] & 0 \\
\hline 20 & $\begin{array}{l}\text { I wonder why the Bee chosse this } \\
\text { flower to pollenate. I wonder why } \\
\text { this bee likes me so much? }\end{array}$ & 3 & [absent] & $\mathrm{n} / \mathrm{a}$ \\
\hline 19 & $\begin{array}{l}\text { I wonder why the Bees likes this } \\
\text { flower more then the others? }\end{array}$ & 3 & [absent] & $\mathrm{n} / \mathrm{a}$ \\
\hline 1 & [absent] & $\mathrm{n} / \mathrm{a}$ & I wonder how 7 leafs can fit in 1 leaf & 4 \\
\hline
\end{tabular}

*All of the statements are presented as the students wrote them, including misspellings. 
For weeks three and four (pollinator observation and leaf drawing in pairs), we compared the average of the art scores with the question scores using a regression analysis and found that there was a correlation. High art scores occurred with high question scores for week three (Figure 1$)(\mathrm{n}=18, \mathrm{p}=0.001)$ and for week four $(\mathrm{n}=17$, $\mathrm{p}=0.002$ ). When we compared detail scores with question scores, we found a correlation for week three (Figure 2) $(\mathrm{n}=18, \mathrm{p}=0.010)$, but not for week four $(\mathrm{n}=17, \mathrm{p}=0.857)$. The high question scores for week four would have been due to factors other than detail.

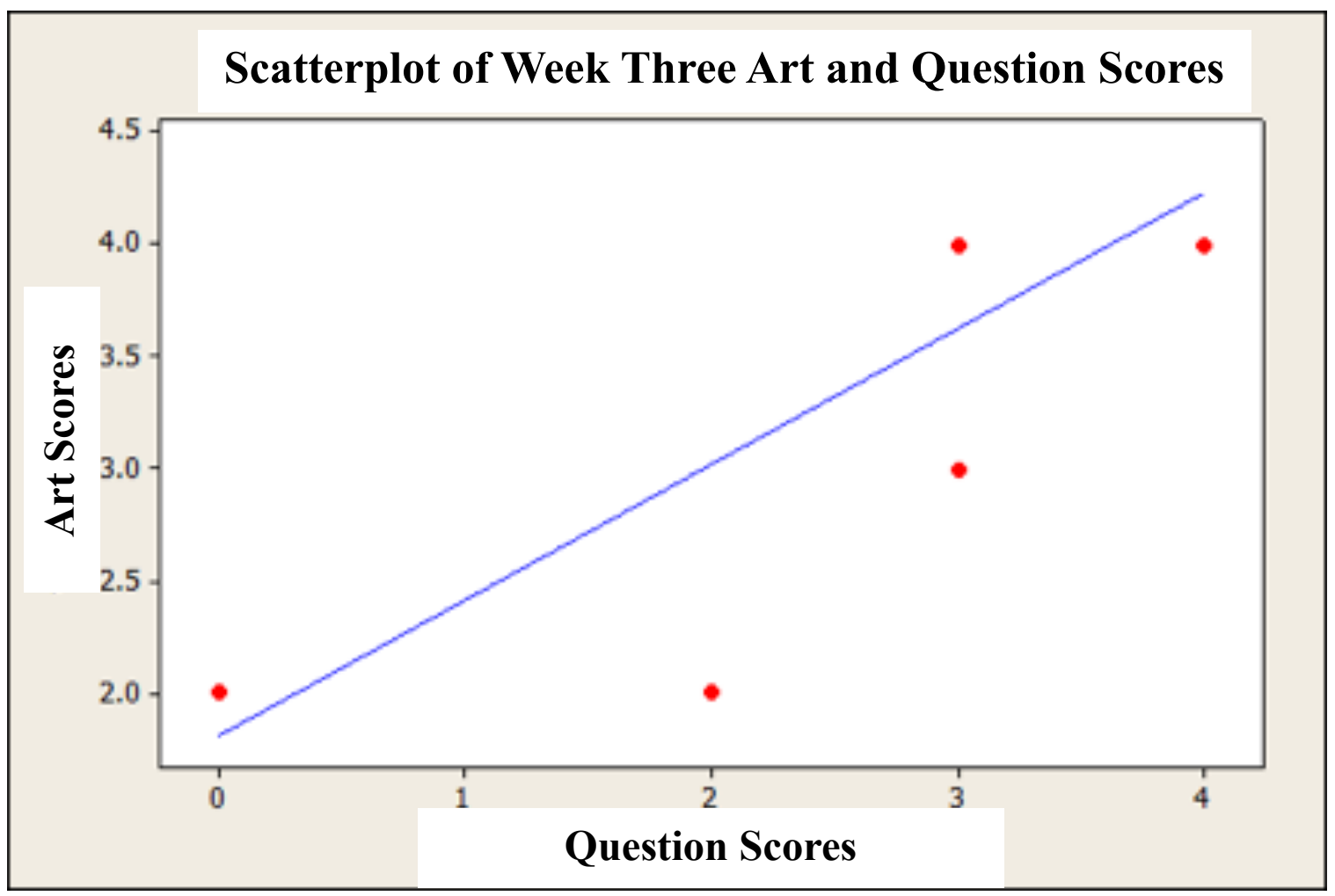

Figure 1. Week Three Art Scores Correlate with Question Scores 


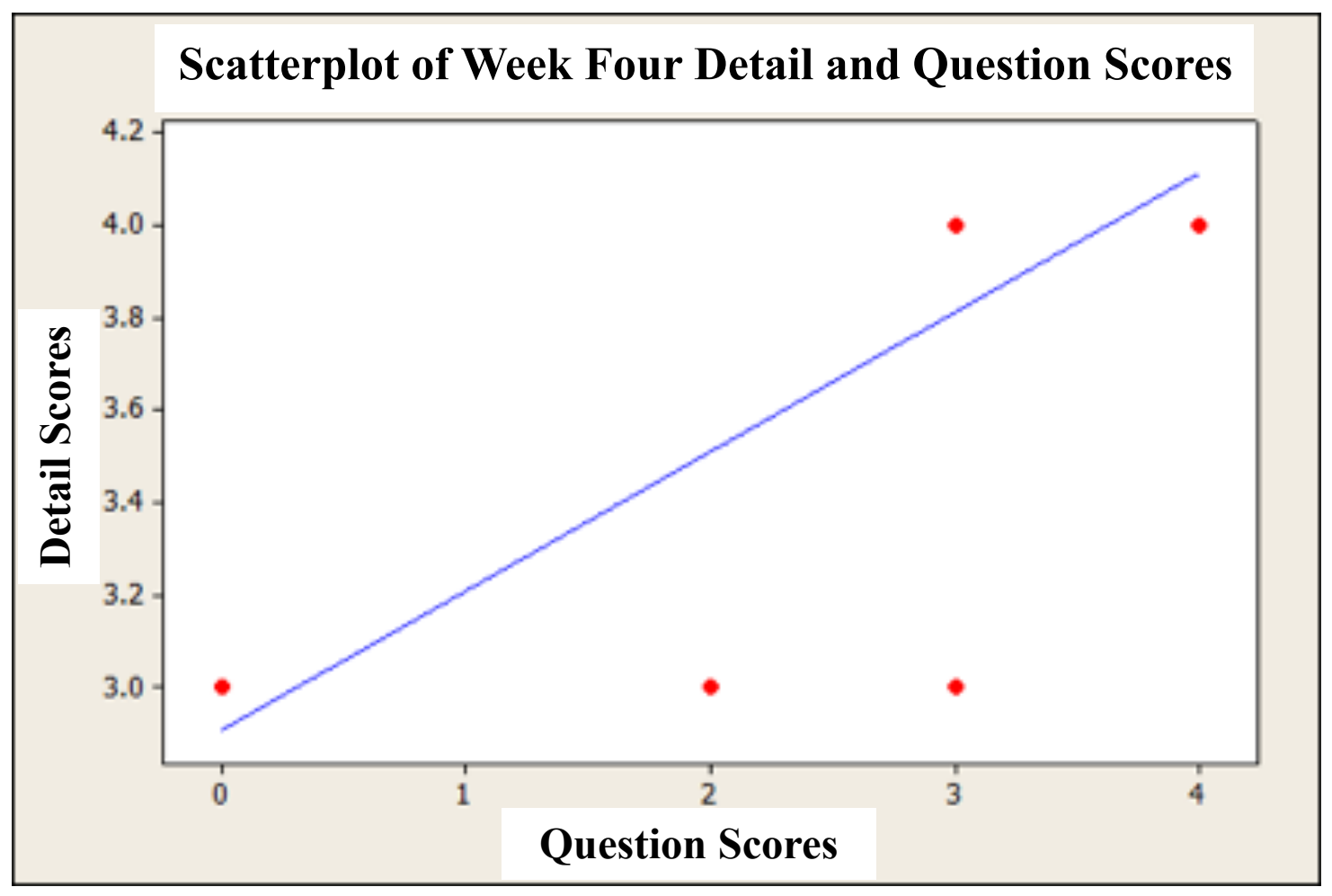

Figure 2. Week Three Detail Scores Correlate with Question Scores

When we looked at possible changes of scores over time, we noticed that the median and mean scores generally stayed the same or declined over time for detail, relevance, and text (Figures $3 \& 4$ ).

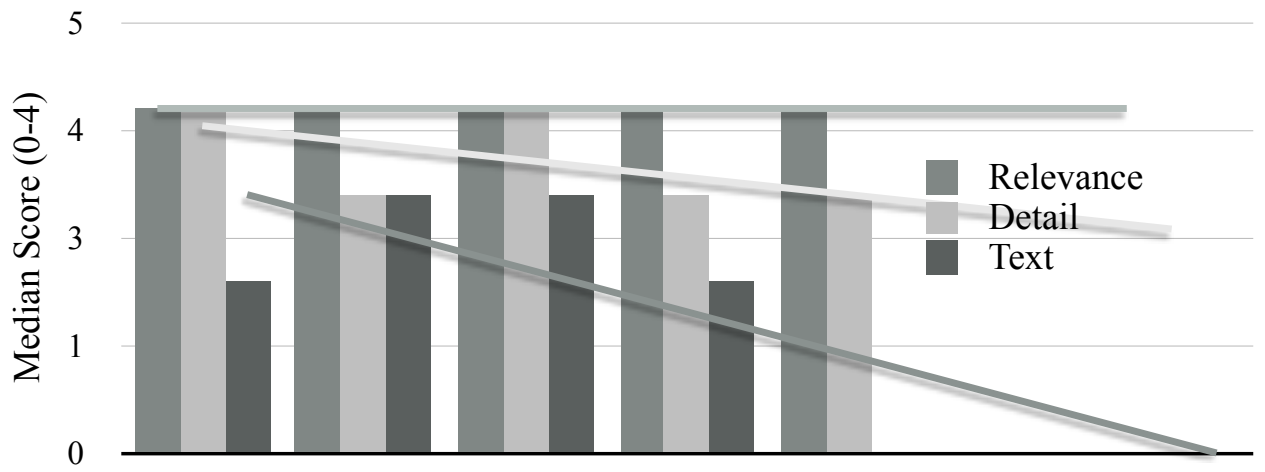

Week (1-5)

Figure 3. Median Score for Relevance, Detail, and Text 


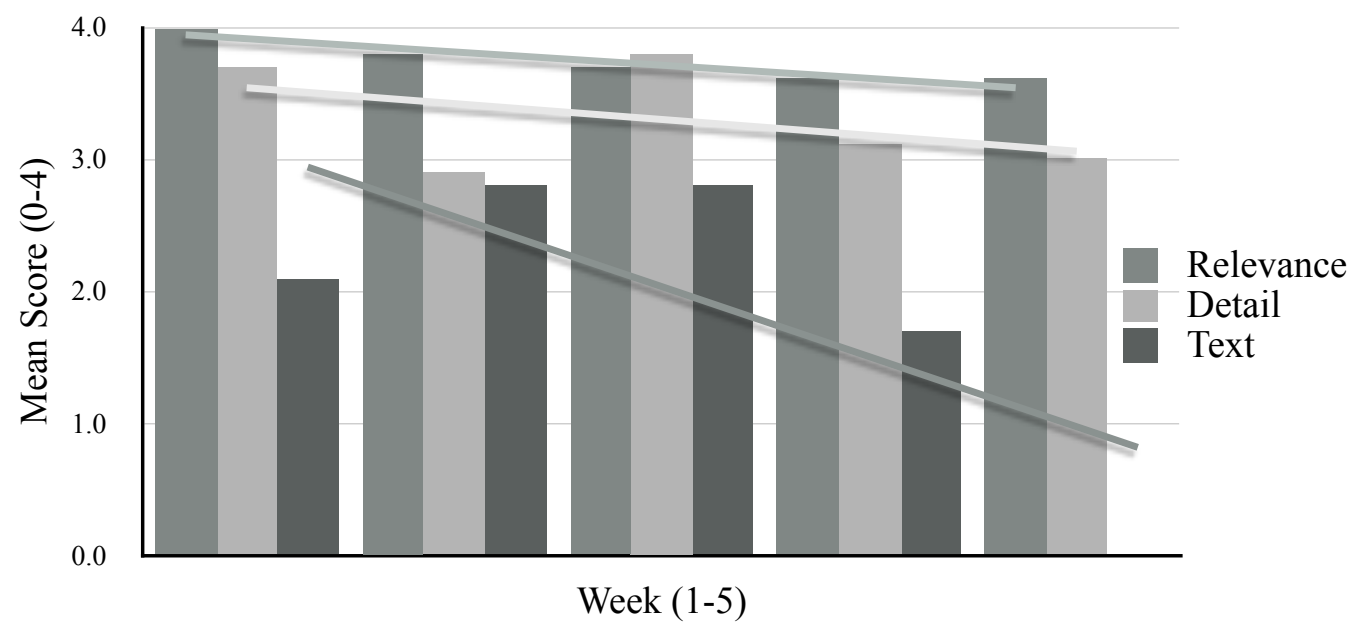

Figure 4. Mean Score for Relevance, Detail, and Text

\section{Research Question 2: In what ways are student learning and perspectives of science affected by the art strategy?}

After listening to the interviews three times and taking notes, I came up with the

following eight codes for the main ideas students mentioned:

$\mathbf{R}$ Artwork as a way to recall the science lesson and observations.

OB Student observed more thoroughly.

CT Student made a personal connection to school or home.

Q Question formation processes.

D Drawing as a learning tool.

C Challenging to draw.

E Engaged or excited about lesson or science.

I went through each interview one more time and wrote down and coded exact quotes from the students. I combined some of the codes to support the main themes that arose. The full list of interview statements and quotes are organized by code in Appendix 
D. This is a description of the themes, and how the coded responses were combined to form the themes:

Observations Create Questions (OB \& Q): Students were able to observe more thoroughly. Students said their observations sometimes directly led to "I wonder questions" and some said the questions "just popped into their head."

Drawing Helps, and is Challening (D \& C): While drawing can be helpful in learning about a topic, the process can also be challenging.

Connection to Science (R, CT, \& E): The lessons helped students to recall their science observations, make personal connections, or become engaged in science.

\section{Theme 1: Observations Create Questions}

There were a total of 25 statements for this theme, with almost all of the interviewees commenting about observing thoroughly $(n=8)$ and all of the interviewees ( $\mathrm{n}=9$ ) commenting about how they formed their questions, though how students came up with their questions differed. The Observations Create Questions theme was by far the most supported by students' statements.

Students 5, 21, 1, and 8 made at least two comments related to observing more closely and thoroughly. For example, student 5 was able to observe more closely than she realized was possible: "I never really looked at bees that way. I never really noticed them completely. It's like a lot of people notice that they might sting you, that you have to run away. A lot of people kind of think that. So I kind of really looked at them and saw what an actual bee is kinda. I saw the bee." 
Student 21 noticed that the actual color of an object was a combination of many colors when she stated, "You would think that strawberries are actually one color but they're actually pinky and purply and black. Black's basically the spots and I saw green. The black and the green were the spots." Student 1 also saw more layers of detail when she commented, "I saw the same thing, but I looked at them a little more closely and saw a couple different things. You can see that the little brown spots are seeds when you look really close at the strawberries."

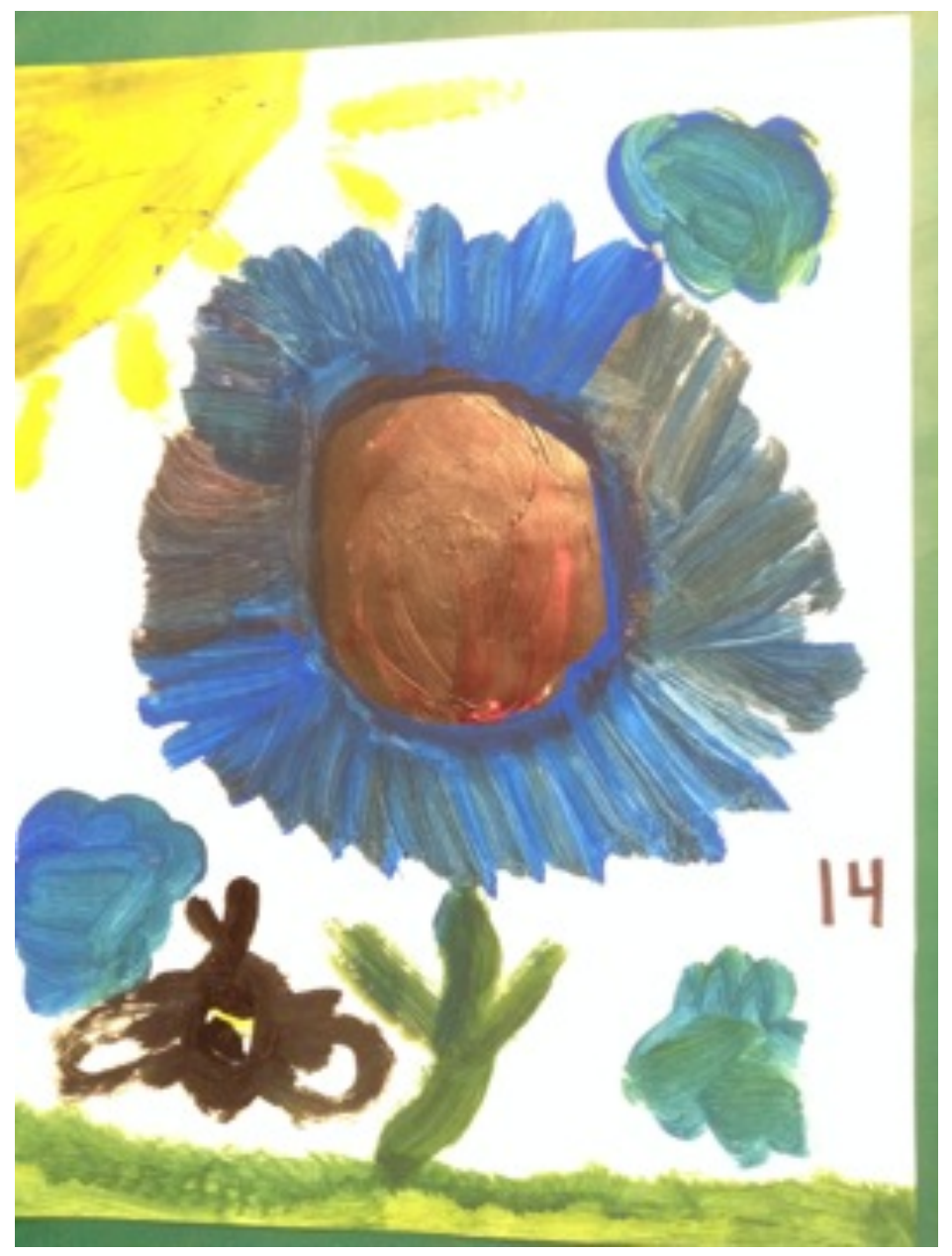

Figure 5. Student 14's painting from week five. 
Student 14 recognized the difference between a casual glance and the detail of a full observation. She commented that observing helped her to see the pollinators, notice patterns, and "look closer at the plant than I had done before that." She said that when she usually walks past a flower, she only notices it's dominant color and then she walks away. Using the art strategy to observe closely caused her to "think more about the flower... And really go into it. It's a blue flower. It's a little pointy. There's a bee going around it. And, it's like spiky kind of. The middle's red" (Figure 5).

In terms of question formation, all of the students chose to discuss their "I wonder questions" though how they thought they came up with the question differed. For example, student 12 commented that she saw lots of bees and was wondering why they have yellow and black stripes. Student 1 observed a compound leaf and said, "It's kinda weird when you look at one leaf and you see seven of them but they're all connected to the same stem. You could think of it as seven different leaves but you could also put it as one leaf" (Figure 6). 


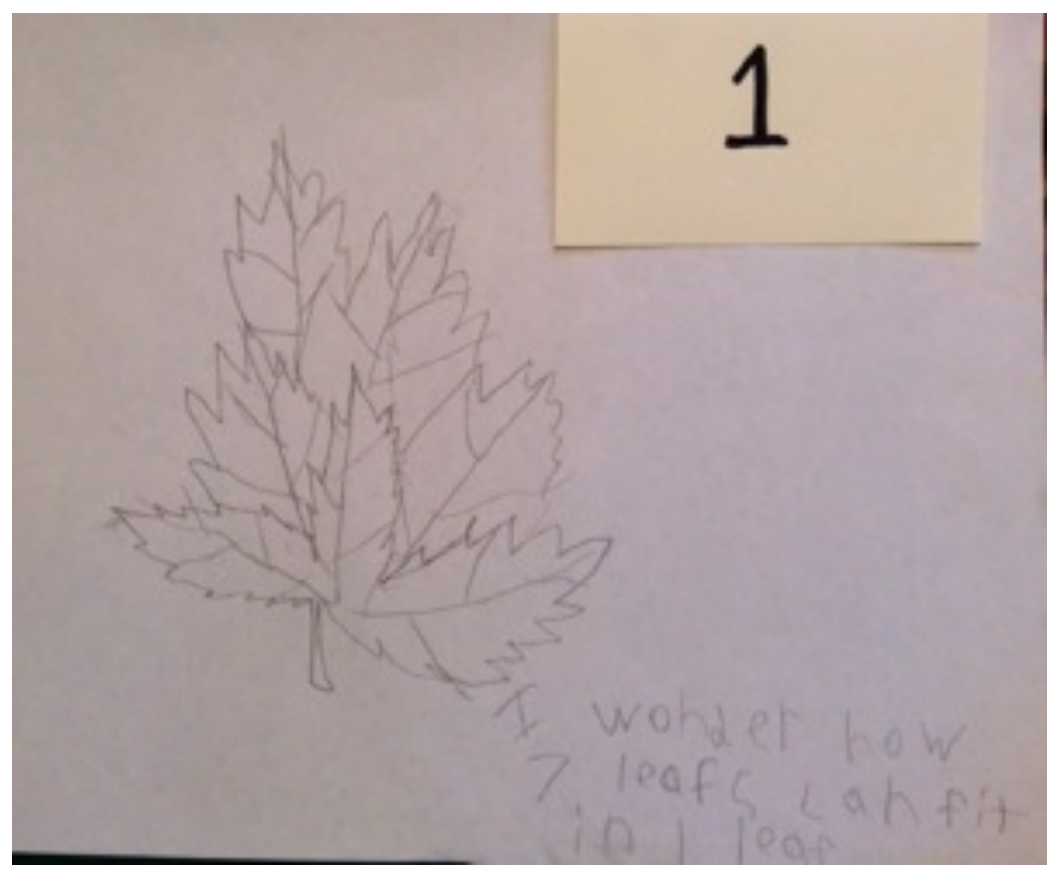

Figure 6. Student 1 wondered "How 7 leafs can fit in 1 leaf" during lesson four.

Many students observed pollinators on plants and were wondering why bees chose certain flowers. Student 6 wondered why bees liked "this flower best" and had noticed, "There was a lot of bees on there and not on so many other flowers, so I wrote that down." Student 13 commented, "I wonder why the bee landed on the raspberry flower. Like the bee, there was a raspberry on the flower." Student 20 also demonstrates how the student questions were often tied directly to their observations when she says, "I came up with this one, well I was wondering if they were attracted to light colors and then I was wondering like why did the bee choose this flower."

Students did not always claim that their questions were directly linked to observations. For example, student 5 talked about how her question "was something I thought up, it just literally popped into my mind" and then continued to talk about how 
"I think we came up with the question as a group. We all put that down." Student 2 also talked about how his question just came to him by stating, "I just did. I was wondering why pine trees have needles instead of leaves" (Figure 7). Student 21 came up with one of her questions before the observational drawing, wondering how many pollinators she would see and then counting pollinators while drawing. Still, these students' questions were related to the pictures that they drew and the content of the lessons.

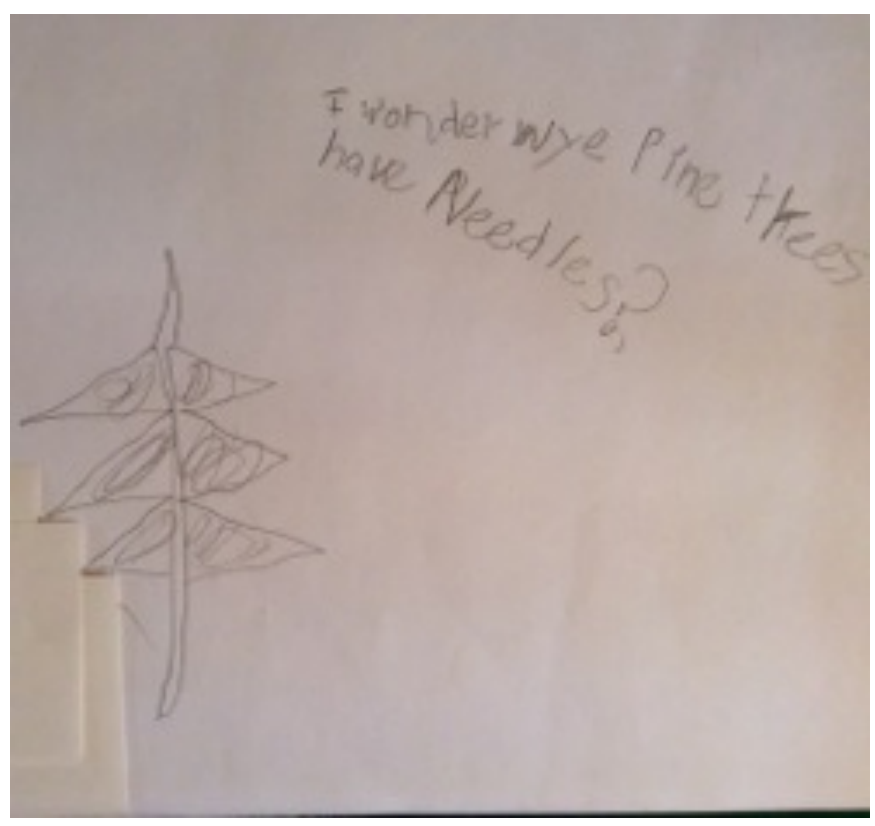

Figure 7. Student 2 said his question just came to him during lesson four.

\section{Theme 2: Drawing Helps and is Challenging}

While some students talked about how drawing helped them to make observations or understand science, others commented on the difficulty in executing the drawings. Student 5 recognized that different mediums of art used to record were helpful stating, "I 
just thought that it just would help some day because it's a lot of things I haven't noticed before, like for instance, even in the beginning of painting something" (Figure 8).

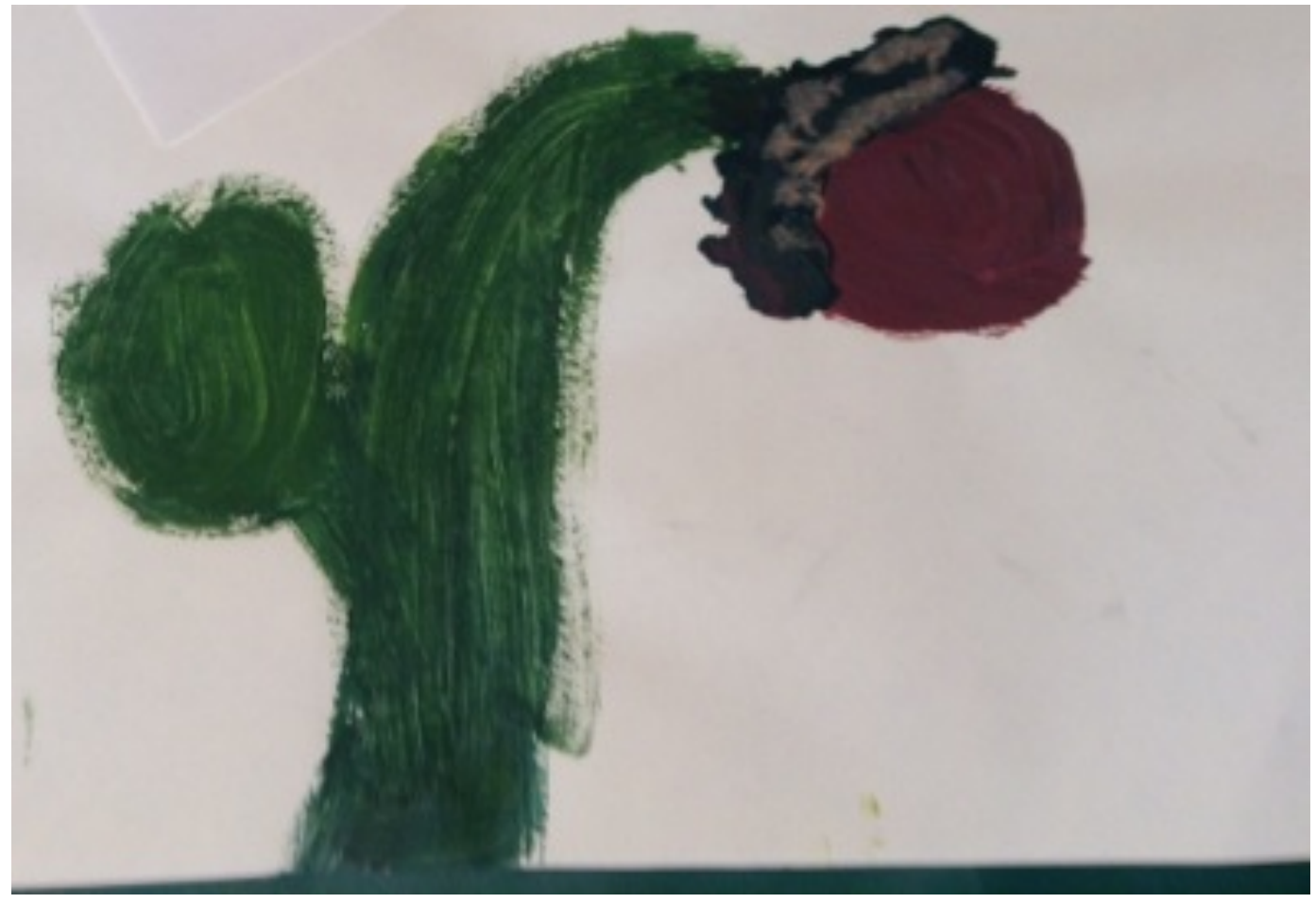

Figure 8. Student 5 said that even painting helps her notice.

Three students actually commented that they like or love to draw. Student 6 mentioned that using drawing as a tool helps her understanding and said, "It's sometimes easier to draw things or read things than listening to things. So it helped me to learn things better." 


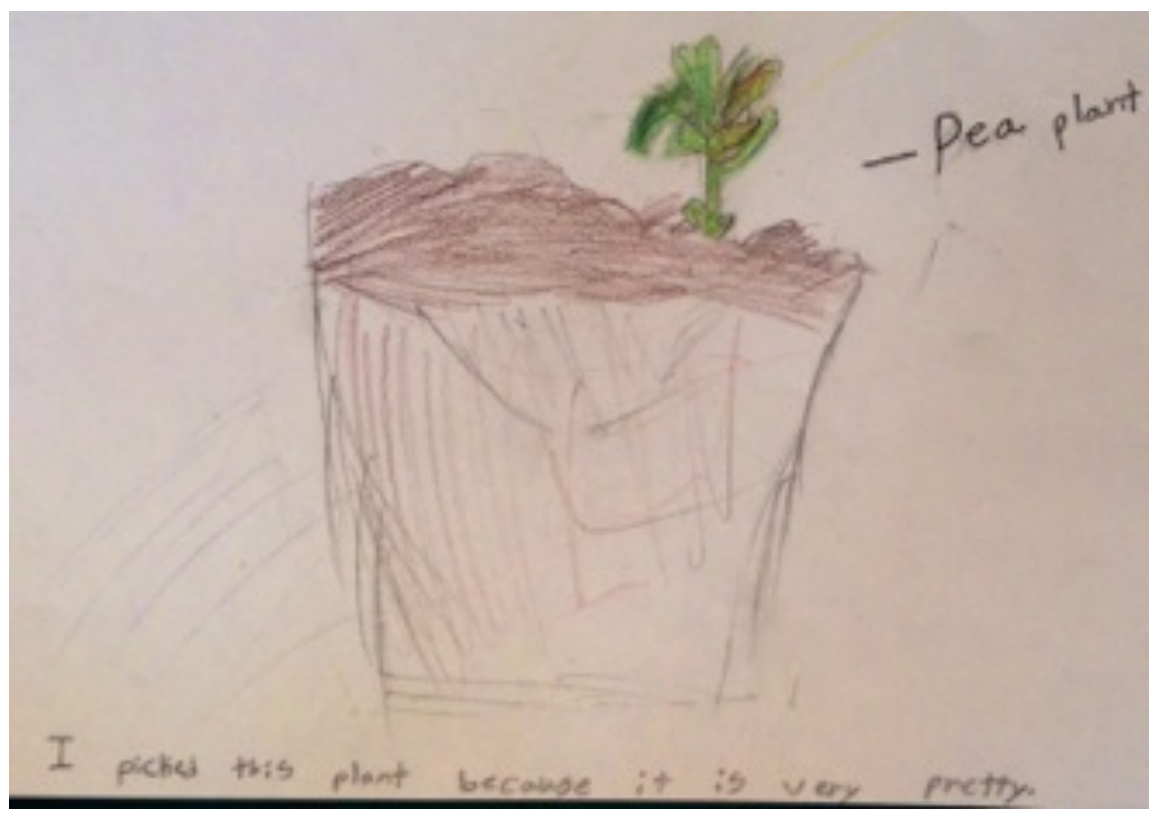

Figure 9. Student 6 connects to the drawing aspect of the lesson during week one.

Student 14 talked extensively about how the drawing process helped her observe:

"This helped me a lot. Like the pictures, actually going in looking at the plant and drawing it. I love to draw. It's a different type of drawing. I usually draw people. I don't know why but I love to do that. This helped me open up like a type of way to draw. Sometimes I like to draw realistic and sometimes I don't. And the people are not really realistic and the flowers are so this gives me both of each."

While students discussed outwardly how drawing was helpful, they also recognized the difficulty in capturing exactly what they observed. For example, student 20 said, "I think that this was supposed to be dark green and this was light to dark," suggesting that if she had access to more color choices during that particular exercise it would be easier to represent her observations. Student 12 also mentioned difficulty representing color, stating, "That brown was really not brown. It looked like brown but now it doesn't really look like brown." 
Student 12 discussed how her artwork did not capture everything she saw by stating, "The painting looked very different than the actual source of plant. Because the plant's more alive than a painting." Student 21 talked about how sometimes it was difficult to see tiny things when she stated, "The one where we did comparison was hard for me because the younger one was much smaller; it was difficult to see on the smaller one; that compared to that" (Figure 10). This student also noticed that drawing pollinators was challenging because insects move and it was difficult to “make sure you weren't doing the same bee." She also recognized the difficulty in the partner draw and recommended the partner be required to describe four or five details. Another student also noticed this difficulty. One student said painting was challenging because we forgot to bring water outside. Altogether, the art strategy was both helpful and challenging.

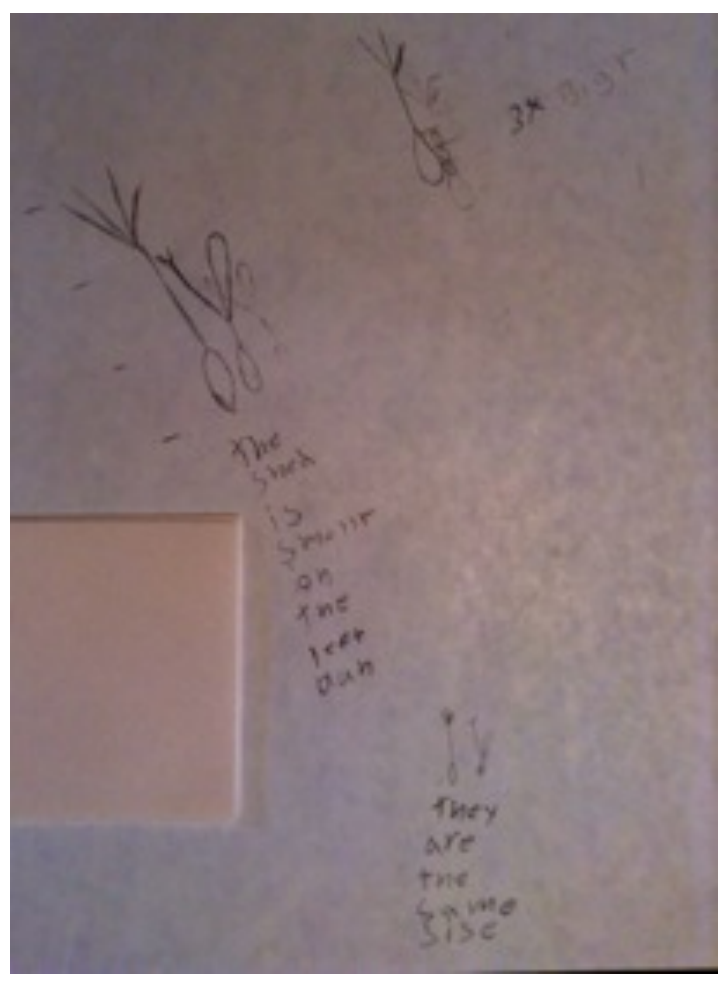

Figure 10. Student 21 said she had difficulty making size comparisons for lesson two. 


\section{Theme 3: Connection to Science}

When I asked students to tell me about their work, two-thirds of them used their drawings to easily recall their observations. Student 5 was able to remember her observations by what she drew stating, "Only when I look back on it can I see what it is because I begin to think to myself that doesn't look like a strong stem. I would think the fruit would be down on the ground or something. So I kinda look back on it and then see." Student 12 similarly was able to describe what she noticed even though she didn't know the name of the plant, stating, "That is a pinecone and I have no clue what that is. It's a stalk with a bean pod and a stem coming out. I don't really know what that's called" (Figure 11).

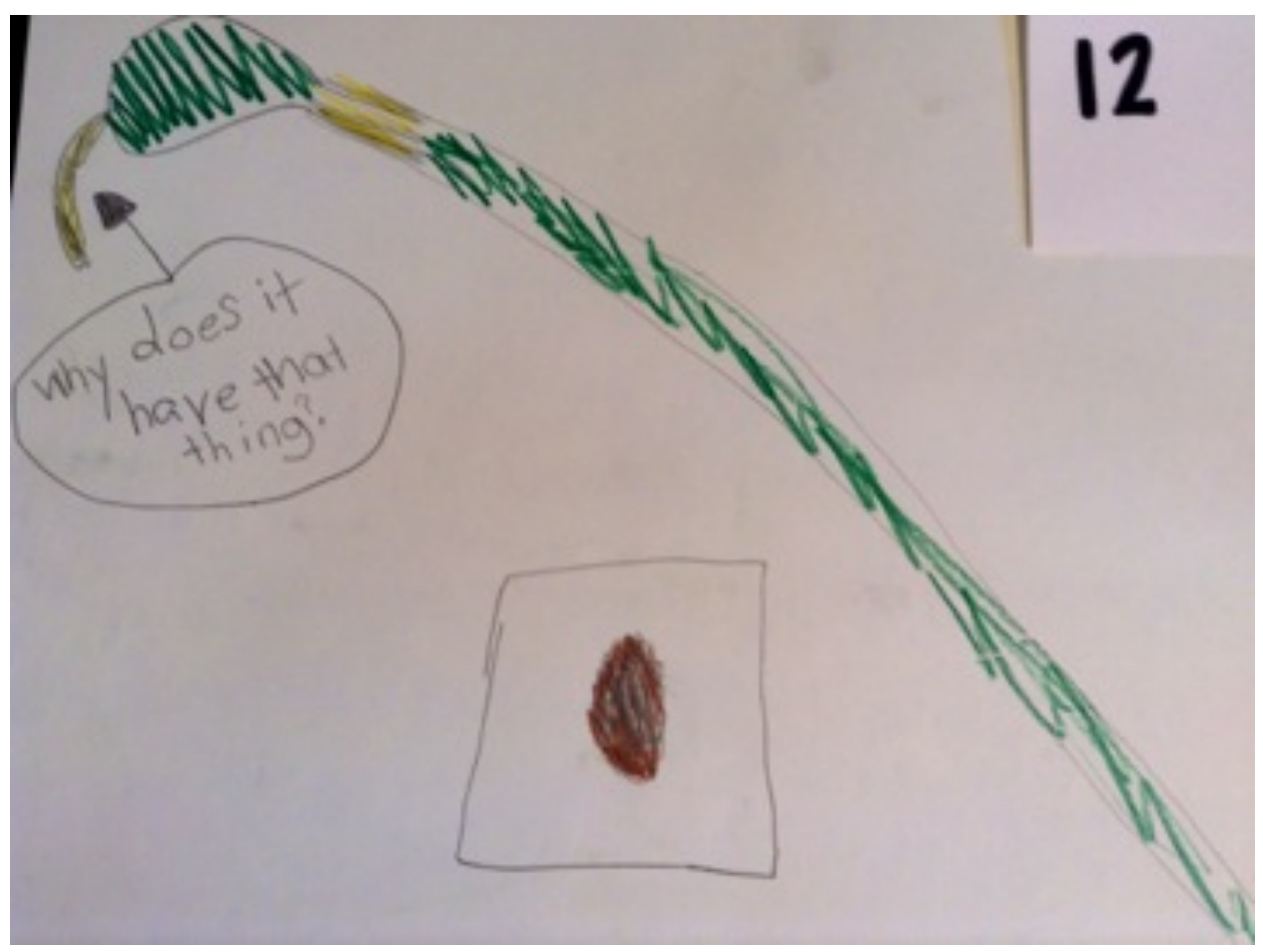

Figure 11. Student 12 recalls her curiosity from the first lesson. 
Three students connected to other personal experiences. Student 12 mentioned planting with the garden educator. Student 2 named the object of observation "Stumpy longnose." Student 14 said her previous experience with plants was related to weeding. She said she "didn't know about them as beautiful plants with insides and like pistils and ovules and peduncles. That type of stuff inside of it."

Students mentioned other ways they were engaged or excited about the science lessons. Student 5 stated, "This could probably help me in science one day, all of these things. I just think that they're, it was really helpful what you taught all of us. That was something that was really good." Student 14 talked about a change in her perception of science, "For a while, it (science) was not my favorite subject in school. I don't know why. Botany helped me feel better about science. I like plants better than I ever have now." When student 13 was asked if the lessons affected the way he thought about science, he smiled and replied, "yes" (Figure 12). And student 20 mentioned how she enjoyed the lessons while also learning when she said, "I think this study was really fun... that I got to draw all these living plants and that we got to just dig a little deeper into science" (Figure 13). 


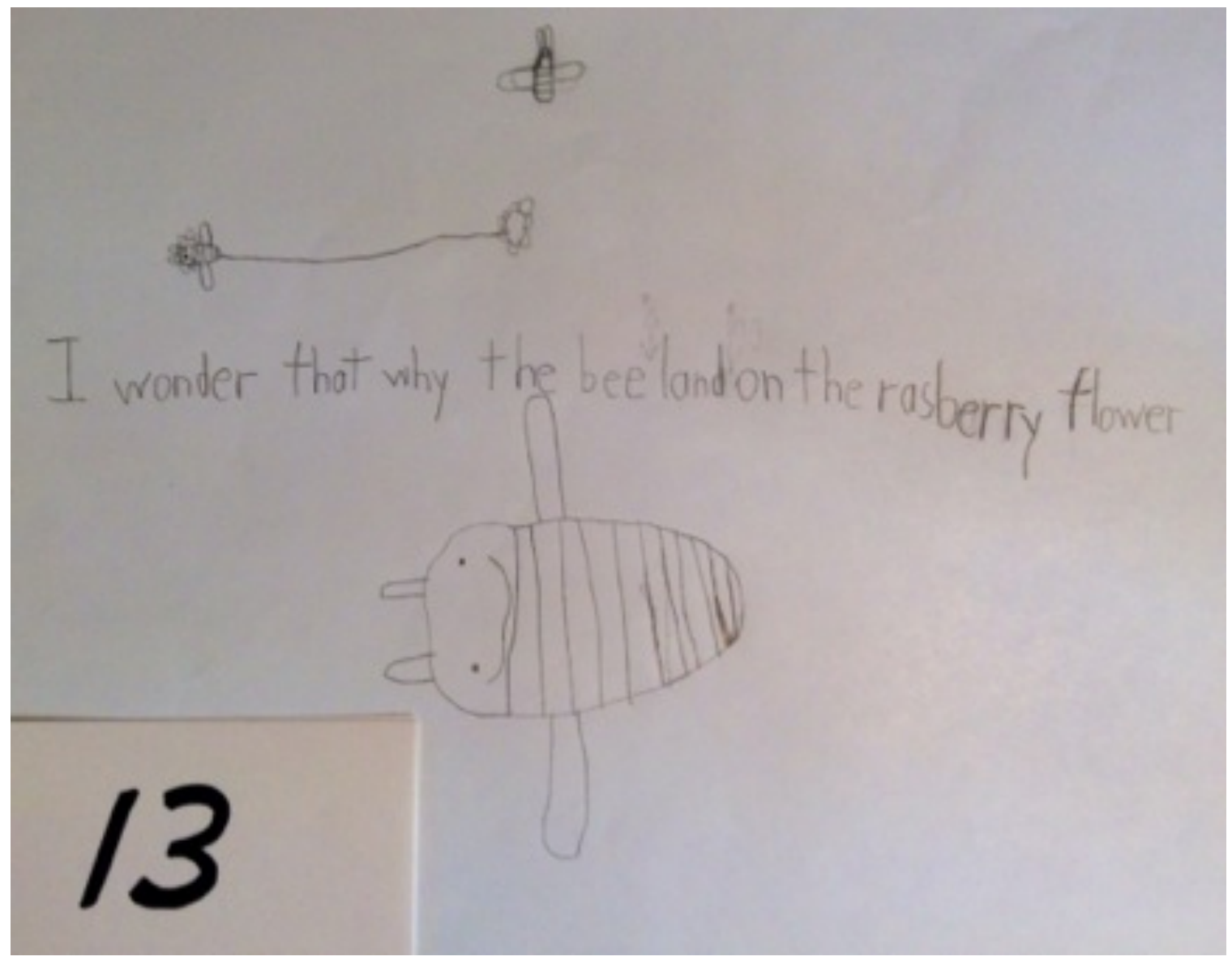

Figure 12. Student 13 thinks about bees and raspberry flowers during lesson three. 


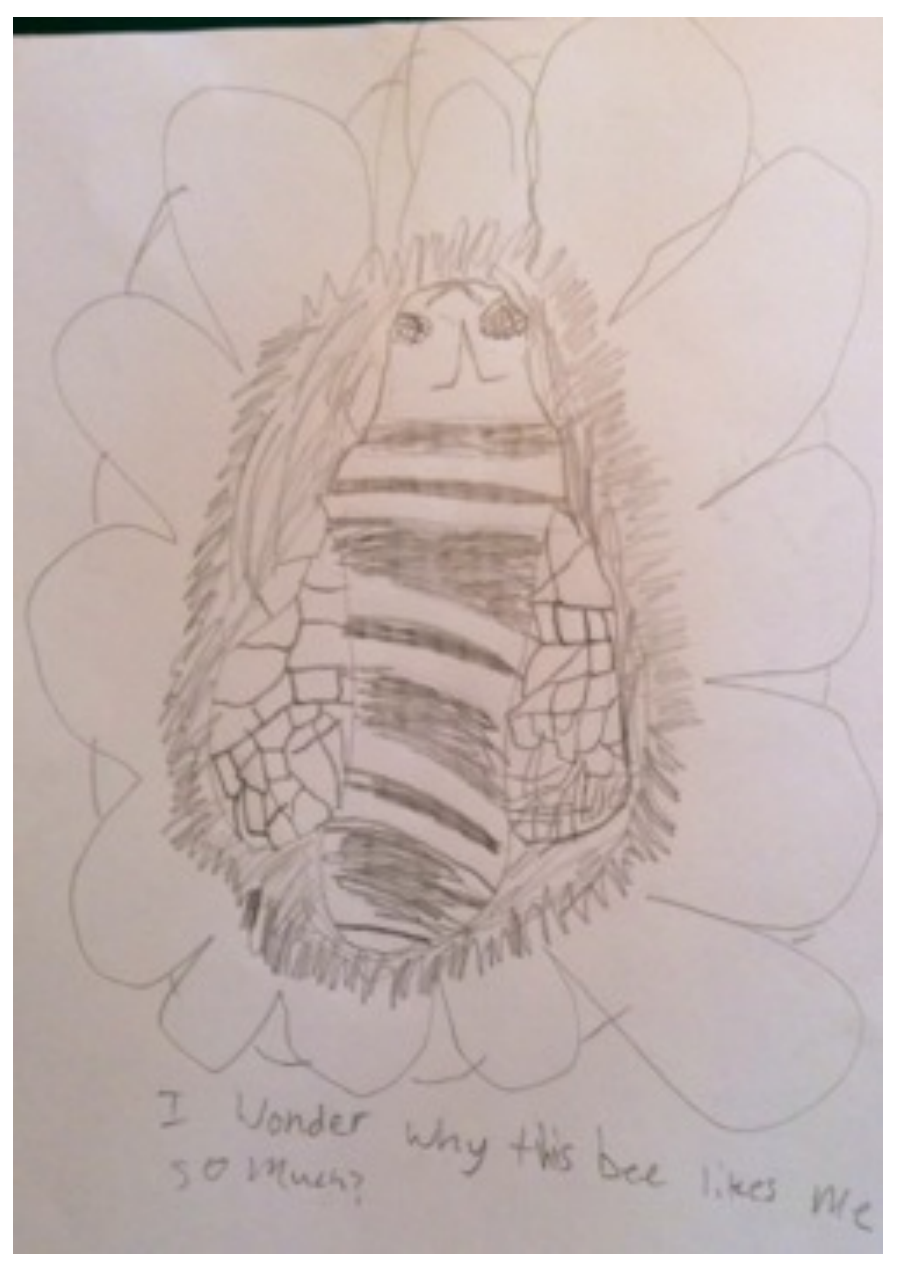

Figure 13. Student 20 said the lessons were fun and she learned more about science

\section{Other Observations}

I noticed a few other things that are not significant enough to create more themes, but are interesting nonetheless. All of the students said that they did not use the strategies taught in the lessons in any other classes. When asked about what the kids would do differently, many said they wouldn't change anything. One student said she would have liked her partner to use more details to describe the leaf. And, two students wanted even more active activities like planting a plant or a botany scavenger hunt. 


\section{Discussion}

I examined how an art strategy observing the local environment could help third graders to make observations and ask questions. I also looked at the ways student learning and perspectives of science were affected by the art strategy. Through scoring student work using rubrics and interviewing students, I found that the strategy allowed students to make strong observations and strong questions. Most of the interviewed students said the art strategy helped them to make observations, that drawing was helpful and challenging, and that the strategy helped connect them to science.

Traditional models of science teaching involve teacher generated questions about phenomena, the use of pre-made kits, or teacher-led observations. Many teaching strategies and lesson plans focus on teachers asking questions without giving students the chance to ask or explore their own questions. Students may be given a question to explore or a science-kit and asked to fill out worksheets highlighting the "scientific method." Or, teachers ask questions about what students are observing, limiting the potential for students to come up with their own questions. These practices thwart the initial steps of scientific questioning. It is important for teachers to use strategies where students develop their own questions and then explore those questions through investigations.

The traditional strategies mentioned above usually require students to form a hypothesis about the question they were given and make observations or experiment. The hoped-for result is that new knowledge is gained. Another approach, like the one used in this study, allows for more student generated questions. This approach is more realistic to 
everyday life and consists of students beginning to observe a scenario or object in its natural environment and using drawing to record. The students would use their observations to generate questions. The observation and questioning could repeat several times before the questions were followed up with research or investigations that involve experimenting or more observation. The final result is authentic new knowledge is gained and scientific practices are learned as well.

Investigations do not need to always begin with a question or the teacher providing a question. Observations can precede investigations, especially when students say that they do not have any questions or are unsure what they are wondering about. As students use art to make observations, questions begin to "pop into their heads" as some students stated during my study. It is important to note that there may be a difference in metacognition, specifically how students think they know something. When students say something popped into their head, they may notice that the question appeared without recognizing that the observation actually stimulated the question. Nonetheless, students are capable of coming up with their own questions and we cannot expect them to do so without providing the chance to observe and explore what we want them to wonder about. We need to use art to engage students in making observations and forming questions. Art can help us to observe more thoroughly, create questions, become engaged and challenged, and connect to science.

As Eberbach and Crowley (2009) suggest, observation has many functions throughout scientific investigation. As teachers, we want to help students develop ways to 
ask questions, not simply give them questions and collect data or ask them to hypothesize what will happen next. The Next Generation Science calls for students to be able to ask questions. The K-12 Framework for Science Education calls for students to be able to record observations too, stating, "At the elementary level, students need support to recognize the need to record observations - whether in drawings, words, or numbersand to share them with others." Thus, making observations and asking questions are crucial parts of science education.

My study has shown how using art to make observations can assist in scaffolding student question-formation. Using an open-ended activity like observational drawing taps into the creative aspects of science and results in student-driven explorations. When Eberbach and Crowley (2009) mention that children spontaneously make drawings and yet students often don't want the responsibility of recording observations, they provide rationale for the possibly of using drawing to record observations. In my study, most kids were enthusiastic about making observations using art. In the interviews, students mentioned how they liked or loved to draw. And, the observations that they made were overwhelmingly relevant and detailed.

The students had strong observations, which correlated with strong questions. For three out of four rubric analyses, there were significant correlations between student artwork and question scores. It is important to note that we measured correlations and not necessarily causation. The analysis of detail and questions shows that the two factors were not correlated for week four (leaf drawing in pairs), and upon further examination 
you see that four students did not write any question down during week four whereas only one student did not write a question for week three (pollinator observations). Each student that did not write a question down scored a zero for questions. I think this could be because the students were a little rushed during week four when I asked them to write down their "I wonder" question at the end of the lesson. For week three, I had asked students to write down "I wonder" questions before they even started drawing. There were also more instructions during week four because the complexity of the partner draw rather than the less structured pollinator draw, which could have resulted in less students writing down a question.

Future lessons could include the "I wonder" prompt on every page of student work so that students do not forget to write down a question and to enhance scaffolding. This would remind kids and the instructor that the question is an important part of the lesson. The importance of scaffolding is consistent with the study by Eberbach and Crowley (2009), who state that scaffolding and structure are necessary for students to make strong observations, which can lead to questions. Chin and Brown (2002) state that unstructured observation time helps students to generate questions, and the authors also call for providing strong supports when directing students in question generation. Chin and Brown claim we need more research on strategies that can help scaffold student generated questions. My study directly connected observation with question formation through using an art strategy that allows students to generate their own questions. The lessons allowed for unstructured observation time. 
Observation relevance was high for all students throughout my study, indicating that most students understood the lesson requirements and chose to participate fully. I would argue that high relevance indicates high engagement. The scores for detail were next highest overall, with students receiving lots of $3 \mathrm{~s}$ or $4 \mathrm{~s}$. Student drawings often contained many layers of detail or many different drawings on one page. Text scores were the lowest of the three categories, with students not writing any text on week five (unstructured observations) other than one student who titled her picture with her name followed by "strawberries." I did not prompt students to write as I had in the previous four weeks. I wondered if they would label their work or write "I wonder" questions. Again, this is evidence that specific instruction is needed for students to write down text or questions. It may also be that drawing and coming up with questions is plenty to focus on during one lesson, and that painting adds a layer of logistic complexity. There was a lot of focus on mixing paints, getting all the materials into the garden, and cleaning up.

The interviews support the rubric data and paint a bigger picture of what students learned. The students said that the lessons helped them to observe better, that drawing could be both helpful and challenging, and that they were aware of connections to science. For some students, the strategy was especially valuable in scientific observation and question formation. For others, it was a valuable tool for engagement.

It is important for teachers to give their students the opportunity to come up with their own questions. So often science is introduced in the form of canned experiments or simple baking soda and vinegar volcanoes asking kids what they predict will happen and 
then trying to wow them. However, science is not always explosive and findings are not always significant. Furthermore, kids are curious and will come up with interesting questions given the chance to observe natural phenomena. The teacher needs to provide students with rich opportunities to generate and investigate their own questions.

Outdoor learning provides the setting for where and how to generate science lesson material. There is a rich array of botanical concepts to study even in the local urban environment. Adding a layer of art into science studies can help to engage students in deeper observation and question formation. In this study, I noticed the kids were in charge of their learning. Students could easily recall lessons using their art. They noticed natural phenomenon and were engaged. As a teacher, I was more engaged too.

There are some limitations to this study. First, I was unable to include pre- and post-test survey data that I collected. While I had the assent of most of the students, most did not put their names on the top of the surveys so I did not know which surveys could or could not be included. I also did not have access to a second class as a comparison group to make the study experimental rather than a case study. I did not know exactly what the primary teacher was teaching each week, making it difficult to match lesson content. In addition, some of the science interest may have been generated by the primary teacher. The students had lessons on identifying and labeling parts of fruits and flowers, which one student mentioned generated interest in science during the interviews. My study provides more evidence that learning through the arts can be an effective means of learning science. I found that teachers need to remind kids to generate 
questions and use descriptive words or labels during a lesson. A teacher needs to give kids ample time to generate questions and text that explains their thinking in addition to the drawing or painting. I also think that making the art lessons relevant to other topics in the curriculum can make it easier for students to make connections between art and science. I would recommend teaching drawing techniques to help students feel confident in their drawing abilities, therefore encouraging stronger science observations and representations. By providing a strong structure for students to exercise their creativity, teachers can help creativity blossom. Students can engage in higher order thinking skills and the practices of science by making observations and questions through art.

\section{Where do we go from here?}

Followup to the lessons presented in this study could include exploring students actual "I wonder" questions in groups and working with other NGSS practices like arguing from evidence. I would have students share their scientific questions and then choose one question to explore further as a group. Students would examine the one question first individually, recording qualitative and quantitative observations about their topic. Then, students would join their group again to share their new observations and form hypotheses or theories about their questions. Subsequent units would focus more on researching and testing the students' questions, collecting data, and forming conclusions. How to apply the art strategy and "I wonder" questions in groups would best be explored in the beginning or middle of the year to give ample time for following up on questions. 
A study on how this art strategy affects English language learners (ELL) would benefit the broader literature as new studies are emerging that visuals help ELL learners. The ELL population sample size was just too small (one or two students) in this study to find significant relationships.

How can teachers engage students in authentic science? We can start by using strategies to scaffold question generation. We can ask students to use art to record observations of phenomenon that is already in their local environment. We can scaffold the use of an "I wonder" question prompt and follow questions with:

1. Discussing different types of questions (investigative, research) that scientists explore and how these are different than procedural or affective questions.

2. Demonstrating how to research answers to questions or design your own investigations.

3. Give students time to form hypotheses, collect evidence, and explore answers to both types of questions.

We need even more methods to explicitly engage students and draw on researchable and investigative science questions. Follow up research could include working with students to research and investigate the questions that they generated through art observations. Lessons would first focus on whether questions are investigative, research, or affective/process oriented so that students can develop metacognitive awareness of different types of questions. As a class, you could discuss different methods to go about finding answers to different types of questions. Teachers 
need to allow more time to follow up on both student generated research and investigative questions. Research questions could be examined through science texts, credible internet resources, or by inviting an expert from the field into the classroom. Investigative questions could be given to different groups to create a more extensive experiment. 


\section{References}

Achieve, Inc. Next Generation Science Standards. (2014). Retrieved from http:// www.nextgenscience.org/next-generation-science-standards

Berstein, R. \& Berstein, M. (2004). (Eds). Sternberg, R.J., Grigorenko, E.L., \& Singer, J.L. Chapter 8, Artistic Scientists and Scientific Artists: The Link Between Polymathy and Creativity in: Creativity: From Potential to Realization. Washington, D.C.: American Psychological Association.

Chin, C. \& Brown, D. (2002). Student-generated questions: A meaningful aspect of learning in science. International Journal of Science Education 24(5), 521-549.

City of Portland. (2014). Arts Tax. Retrieved from http://www.portlandoregon.gov/ revenue/60076

Creswell, John W. (2013). Qualitative Inquiry \& Research Design: Choosing Among Five Approaches (3rd ed). Thousand Oaks, CA: Safe Publications, Inc.

Daniels, E. (2010). Creating Motivating Learning Environments: What We Can Learn from Researchers and Students. English Journal 100(1), 25-29.

Eberbach, C and Crowley, K. (2009). From Everyday to Scientific Observation: How Children Learn to Observe the Biologist's World. Review of Educational Research 79(1), $39-68$.

Gallas, K. School, L, \& Massachusetts, B. (1991). Art as Epistemology: Enabling Children to Know What They Know. Harvard Educational Review 61(1).

Gardner, H. (2000). Chapter 4 in Intelligence Reframed: Multiple Intelligences for the 21st Century. New York: Basic Books.

Gardner, H. (1983). Frames of Mind: The Theory of Multiple Intelligences. New York: Basic Books.

Holmes, (2002). Creative by Nature: Integrating the arts into Environmental Science Education. Green Teacher 69, 23-28.

Inwood, H. At the Crossroads: situating place-based art education. Ontario Institute of Studies in Education, University of Toronto, Canada. 
Inwood, H. (2009). Artistic Approaches to Environmental Education: Developing Eco-art Education in Elementary Classrooms. Doctoral Thesis. Concordia University, Montreal, Quebec, Canada. January, 2009.

Kudryavtsev, A., Stedman, R.C. \& Krasny, M.E. (2012). Sense of place in environmental education. Environmental Education Research. 18(2), 229-250.

National Research Council. (2012). A Framework for K-12 Science Education: Practices, Crosscutting Concepts, and Core Ideas. Committee on a Conceptual Framework for New K-12 Science Education Standards. Board on Science Education, Division of Behavioral and Social Sciences and Education. Washington, DC: The National Academies Press.

Oregon Department of Education. (2014). Oregon Literacy Task Force. Retrieved from http://www.ode.state.or.us/search/page/?id=2886

Portland Public Schools. About Portland Public Schools (2013). Retrieved from http:// www.pps.k12.or.us/about-us/index.htm

Sarkar, S. and Frazier, R. (2008, February). Place-Based Investigations and Authentic Inquiry. Science Teacher.

Shepperd, P., Donaldson, B.A., \& Huckleberry, G. (2010, November). Quantitative assessment of a field-based course on integrative geology, ecology and cultural history. International Research in Geographical and Environmental Education 19(4), 295-313.

Trimis, E. \& Savva, A. (2009). Artistic Learning in Relation to Young Children's Chorotopos: An In-Depth Approach to Early Childhood Visual Culture Education. Early Childhood Education. 36, 527-539.

Trochim, W.K. (2006). Research Methods Knowledge Base. Retrieved from http:// www.socialresearchmethods.net/kb/intsing.php

Trowbridge, J.E. \& Wandersee, J.H. (2005). Assessing Science Understanding: A Human Constructivist View. In J.J. Mintzes, J.D. Novak \& J.H. Wandersee (Eda). Observation Rubrics in Science Assessment. Burlington, MA: Elsevier Academic Press. 


\section{Appendix A: Scores for Reliability of the Rubrics}

\begin{tabular}{|c|c|c|c|c|}
\hline \multirow[b]{2}{*}{ Student (\#) } & \multicolumn{4}{|c|}{ Reliability data for the question rubric } \\
\hline & $\begin{array}{l}\text { Question A (2nd } \\
\text { observer's score) }\end{array}$ & $\begin{array}{l}\text { Question B (2nd } \\
\text { observer's score) }\end{array}$ & Question A (My score) & Question B (My score) \\
\hline 21 & 0 & 3 & 0 & 3 \\
\hline 14 & 4 & 1 & 3 & 2 \\
\hline 1 & 0 & 1 & 0 & 4 \\
\hline 7 & 4 & 0 & 3 & 0 \\
\hline 18 & 3 & 3 & 3 & 3 \\
\hline 19 & 3 & 0 & 3 & 0 \\
\hline 29 & 3 & 0 & 3 & 0 \\
\hline 12 & 3 & 0 & 3 & 1 \\
\hline 5 & 4 & 0 & 4 & 0 \\
\hline
\end{tabular}

\begin{tabular}{|c|c|c|c|c|}
\hline \multirow[b]{3}{*}{ Student A } & \multicolumn{4}{|c|}{ Reliability data for the art work samples } \\
\hline & \multicolumn{2}{|c|}{ 2nd observer's score } & \multicolumn{2}{|l|}{ My Score } \\
\hline & Drawing 1 & Drawing 3 & Drawing 1 & Drawing 3 \\
\hline Relevance & 4 & 3 & 3 & 3 \\
\hline Detail & 2 & 3 & 2 & 3 \\
\hline Text & 1 & 0 & 1 & 2 \\
\hline Student B & Drawing 1 & Drawing 2 & Drawing 1 & Drawing 2 \\
\hline Relevance & 4 & 4 & 4 & 4 \\
\hline Detail & 4 & 4 & 4 & 4 \\
\hline Text & 1 & 1 & 2 & 4 \\
\hline Student C & Drawing 1 & Drawing 2 & Drawing 1 & Drawing 2 \\
\hline Relevance & 4 & 4 & 4 & 4 \\
\hline Detail & 3 & 3 & 3 & 4 \\
\hline Text & 1 & 2 & 2 & 2 \\
\hline Student D & Drawing 1 & Drawing 2 & Drawing 1 & Drawing 2 \\
\hline Relevance & 4 & 0 & 4 & 0 \\
\hline Detail & 3 & 0 & 4 & 0 \\
\hline Text & 1 & 0 & 2 & 0 \\
\hline
\end{tabular}


Appendix B: Internal Reliability Scores

\begin{tabular}{|c|c|c|c|c|c|}
\hline \multicolumn{6}{|c|}{$\begin{array}{l}\text { Note: I took the first five papers that I scored and then scored those same papers again in the } \\
\text { middle and at the end. Here are all three scores. }\end{array}$} \\
\hline & Student \# & $\begin{array}{l}\text { Criteria 1: } \\
\text { relevance }\end{array}$ & $\begin{array}{l}\text { Criteria 2: } \\
\text { detail }\end{array}$ & $\begin{array}{l}\text { Criteria 3: } \\
\text { text }\end{array}$ & $\begin{array}{l}\text { Question } \\
\text { Score }\end{array}$ \\
\hline \multirow{5}{*}{$\begin{array}{l}\text { First round of } \\
\text { scoring }\end{array}$} & 2 & 4 & 4 & 3 & 4 \\
\hline & 22 & 4 & 4 & 3 & 3 \\
\hline & 3 & 4 & 3 & 3 & $\mathrm{n} / \mathrm{a}$ \\
\hline & 28 & 2 & 2 & 1 & 2 \\
\hline & 3 & 4 & 4 & 3 & $\mathrm{n} / \mathrm{a}$ \\
\hline \multirow{5}{*}{$\begin{array}{l}\text { Second round of } \\
\text { scoring }\end{array}$} & 2 & 4 & 3 & 3 & 4 \\
\hline & 22 & 4 & 4 & 3 & 3 \\
\hline & 3 & 4 & 3 & 3 & $\mathrm{n} / \mathrm{a}$ \\
\hline & 28 & 2 & 3 & 1 & 2 \\
\hline & 3 & 4 & 4 & 3 & $\mathrm{n} / \mathrm{a}$ \\
\hline \multirow[t]{5}{*}{ Final scoring } & 2 & 4 & 3 & 3 & 4 \\
\hline & 22 & 4 & 3 & 4 & 3 \\
\hline & 3 & 4 & 3 & 3 & $\mathrm{n} / \mathrm{a}$ \\
\hline & 28 & 2 & 3 & 1 & 2 \\
\hline & 3 & 4 & 4 & 3 & $\mathrm{n} / \mathrm{a}$ \\
\hline
\end{tabular}




\section{Appendix C: Student Drawing and Question Scores}

\begin{tabular}{|c|c|c|c|c|c|c|c|c|c|c|c|c|}
\hline & \multicolumn{4}{|c|}{ Week 1} & \multicolumn{4}{|c|}{ Week 2} & \multicolumn{4}{|c|}{ Week 3} \\
\hline $\begin{array}{c}\text { Student } \\
\#\end{array}$ & Relevant & Detail & Text & \begin{tabular}{|l|} 
Question \\
Score
\end{tabular} & Relevant & Detail & Text & $\begin{array}{l}\text { Question } \\
\text { Score }\end{array}$ & Relevant & Detail & Text & $\begin{array}{c}\text { Question } \\
\text { Score }\end{array}$ \\
\hline 1 & 4 & 4 & 2 & $\mathrm{n} / \mathrm{a}$ & $*$ & $*$ & $*$ & $*$ & $*$ & $*$ & $*$ & $*$ \\
\hline 2 & 4 & 3 & 3 & $\mathrm{n} / \mathrm{a}$ & 4 & 4 & 3 & $\mathrm{n} / \mathrm{a}$ & 4 & 4 & 3 & 4 \\
\hline 3 & 4 & 4 & 3 & $\mathrm{n} / \mathrm{a}$ & 4 & 3 & 3 & $\mathrm{n} / \mathrm{a}$ & 4 & 4 & 3 & 3 \\
\hline 5 & 4 & 4 & 2 & $\mathrm{n} / \mathrm{a}$ & 3 & 3 & 0 & $\mathrm{n} / \mathrm{a}$ & 4 & 4 & 3 & 4 \\
\hline 6 & 4 & 4 & 2 & $\mathrm{n} / \mathrm{a}$ & 4 & 3 & 3 & $\mathrm{n} / \mathrm{a}$ & 4 & 3 & 3 & 3 \\
\hline 7 & 4 & 4 & 4 & $\mathrm{n} / \mathrm{a}$ & 4 & 3 & 4 & $\mathrm{n} / \mathrm{a}$ & 4 & 4 & 3 & 3 \\
\hline 8 & 4 & 3 & 0 & $\mathrm{n} / \mathrm{a}$ & 4 & 2 & 3 & $\mathrm{n} / \mathrm{a}$ & 4 & 3 & 3 & 3 \\
\hline 12 & 4 & 4 & 2 & 3 & 4 & 3 & 3 & $\mathrm{n} / \mathrm{a}$ & 3 & 4 & 4 & 3 \\
\hline 13 & 4 & 3 & 2 & $\mathrm{n} / \mathrm{a}$ & 3 & 2 & 3 & $\mathrm{n} / \mathrm{a}$ & 3 & 4 & 3 & 3 \\
\hline 14 & 4 & 4 & 2 & $\mathrm{n} / \mathrm{a}$ & 4 & 3 & 4 & $\mathrm{n} / \mathrm{a}$ & 4 & 4 & 3 & 3 \\
\hline 18 & 4 & 4 & 4 & $\mathrm{n} / \mathrm{a}$ & 3 & 3 & 2 & $\mathrm{n} / \mathrm{a}$ & 4 & 4 & 3 & 3 \\
\hline 19 & 4 & 4 & 0 & na/ & 4 & 4 & 3 & $\mathrm{n} / \mathrm{a}$ & 4 & 4 & 3 & 3 \\
\hline 20 & 4 & 4 & 4 & $\mathrm{n} / \mathrm{a}$ & 4 & 3 & 2 & $\mathrm{n} / \mathrm{a}$ & 4 & 4 & 3 & 3 \\
\hline 21 & 4 & 4 & 2 & $\mathrm{n} / \mathrm{a}$ & 3 & 3 & 3 & $\mathrm{n} / \mathrm{a}$ & 3 & 3 & 0 & 0 \\
\hline 22 & 4 & 4 & 2 & $\mathrm{n} / \mathrm{a}$ & 4 & 3 & 3 & $\mathrm{n} / \mathrm{a}$ & 4 & 4 & 3 & 3 \\
\hline 25 & 4 & 3 & 0 & $\mathrm{n} / \mathrm{a}$ & 4 & 3 & 3 & $\mathrm{n} / \mathrm{a}$ & 3 & 4 & 3 & 3 \\
\hline 27 & 3 & 3 & 2 & $\mathrm{n} / \mathrm{a}$ & $*$ & $*$ & $*$ & $*$ & $*$ & $*$ & $*$ & $*$ \\
\hline 28 & 4 & 4 & 2 & $\mathrm{n} / \mathrm{a}$ & 4 & 3 & 3 & $\mathrm{n} / \mathrm{a}$ & 2 & 3 & 2 & 2 \\
\hline 29 & 4 & 4 & 2 & $\mathrm{n} / \mathrm{a}$ & 4 & 2 & 3 & $\mathrm{n} / \mathrm{a}$ & 4 & 4 & 3 & 3 \\
\hline 30 & 4 & 3 & 2 & $\mathrm{n} / \mathrm{a}$ & 4 & 3 & 3 & $\mathrm{n} / \mathrm{a}$ & 4 & 4 & 3 & 3 \\
\hline Average & 4.0 & 3.7 & 2.1 & $\mathrm{n} / \mathrm{a}$ & 3.8 & 2.9 & 2.8 & $\mathrm{n} / \mathrm{a}$ & 3.7 & 3.8 & 2.8 & 2.9 \\
\hline Median & 4 & 4 & 2 & $\mathrm{n} / \mathrm{a}$ & 4 & 3 & 3 & $\mathrm{n} / \mathrm{a}$ & 4 & 4 & 3 & 3 \\
\hline
\end{tabular}




\begin{tabular}{|c|c|c|c|c|c|c|c|c|c|c|c|}
\hline & \multicolumn{4}{|c|}{ Week 4} & \multicolumn{4}{|c|}{ Week 5} & \multicolumn{3}{|c|}{ Averages } \\
\hline $\begin{array}{c}\text { Student } \\
\#\end{array}$ & Relevant & Detail & Text & $\begin{array}{l}\text { Question } \\
\text { Score }\end{array}$ & Relevant & Detail & Text & $\begin{array}{l}\text { Question } \\
\text { Score }\end{array}$ & $\begin{array}{c}\text { Average } \\
\text { Art Score } \\
\text { week } 3\end{array}$ & $\begin{array}{c}\text { Average } \\
\text { Art Score } \\
\text { week } 4\end{array}$ & $\begin{array}{c}\text { Average } \\
\text { of all } \\
\text { scores }\end{array}$ \\
\hline 1 & 4 & 4 & 2 & 4 & 4 & 4 & 0 & $\mathrm{n} / \mathrm{a}$ & $*$ & 3 & 3.2 \\
\hline 2 & 4 & 3 & 3 & 3 & 3 & 3 & 0 & $\mathrm{n} / \mathrm{a}$ & 4 & 3 & 3.2 \\
\hline 3 & $*$ & $*$ & $*$ & $*$ & 3 & 3 & 0 & $\mathrm{n} / \mathrm{a}$ & 4 & $*$ & 3.2 \\
\hline 5 & 4 & 3 & 0 & 0 & 4 & 3 & 0 & $\mathrm{n} / \mathrm{a}$ & 4 & 2 & 2.6 \\
\hline 6 & 4 & 3 & 2 & 3 & 3 & 2 & 0 & $\mathrm{n} / \mathrm{a}$ & 3 & 3 & 2.9 \\
\hline 7 & 4 & 4 & 0 & 0 & 4 & 4 & 0 & $\mathrm{n} / \mathrm{a}$ & 4 & 3 & 3.1 \\
\hline 8 & 4 & 4 & 3 & 3 & 2 & 3 & 0 & $\mathrm{n} / \mathrm{a}$ & 3 & 4 & 2.8 \\
\hline 12 & 2 & 3 & 1 & 1 & 4 & 3 & 0 & $\mathrm{n} / \mathrm{a}$ & 4 & 2 & 2.8 \\
\hline 13 & 4 & 2 & 2 & 3 & 4 & 4 & 0 & $\mathrm{n} / \mathrm{a}$ & 3 & 3 & 2.9 \\
\hline 14 & 3 & 3 & 1 & 2 & 4 & 3 & 0 & $\mathrm{n} / \mathrm{a}$ & 4 & 2 & 3.0 \\
\hline 18 & 4 & 4 & 3 & 3 & 4 & 2 & 0 & $\mathrm{n} / \mathrm{a}$ & 4 & 4 & 3.2 \\
\hline 19 & $*$ & $*$ & $*$ & $*$ & 4 & 3 & 0 & $\mathrm{n} / \mathrm{a}$ & 4 & $*$ & 3.1 \\
\hline 20 & $*$ & $*$ & $*$ & $*$ & 4 & 3 & 0 & $\mathrm{n} / \mathrm{a}$ & 4 & $*$ & 3.2 \\
\hline 21 & 4 & 3 & 3 & 3 & 4 & 3 & 0 & $\mathrm{n} / \mathrm{a}$ & 2 & 3 & 2.6 \\
\hline 22 & 2 & 3 & 1 & 1 & 4 & 4 & 0 & $\mathrm{n} / \mathrm{a}$ & 4 & 2 & 2.8 \\
\hline 25 & 4 & 3 & 2 & 4 & 4 & 2 & 0 & $\mathrm{n} / \mathrm{a}$ & 3 & 3 & 2.9 \\
\hline 27 & 4 & 3 & 2 & 3 & 4 & 3 & 0 & $\mathrm{n} / \mathrm{a}$ & $*$ & 3 & 2.7 \\
\hline 28 & 2 & 2 & 1 & 2 & 1 & 1 & 0 & $\mathrm{n} / \mathrm{a}$ & 2 & 2 & 2.2 \\
\hline 29 & 4 & 3 & 0 & 0 & 4 & 3 & 0 & $\mathrm{n} / \mathrm{a}$ & 4 & 2 & 2.8 \\
\hline 30 & 4 & 3 & 3 & 3 & 4 & 3 & 0 & $\mathrm{n} / \mathrm{a}$ & 4 & 3 & 3.1 \\
\hline Average & 3.6 & 3.1 & 1.7 & 2.2 & 3.6 & 3.0 & 0 & $\mathrm{n} / \mathrm{a}$ & & & \\
\hline Median & 4 & 3 & 2 & 3 & 4 & 3 & 0 & $\mathrm{n} / \mathrm{a}$ & & & \\
\hline
\end{tabular}




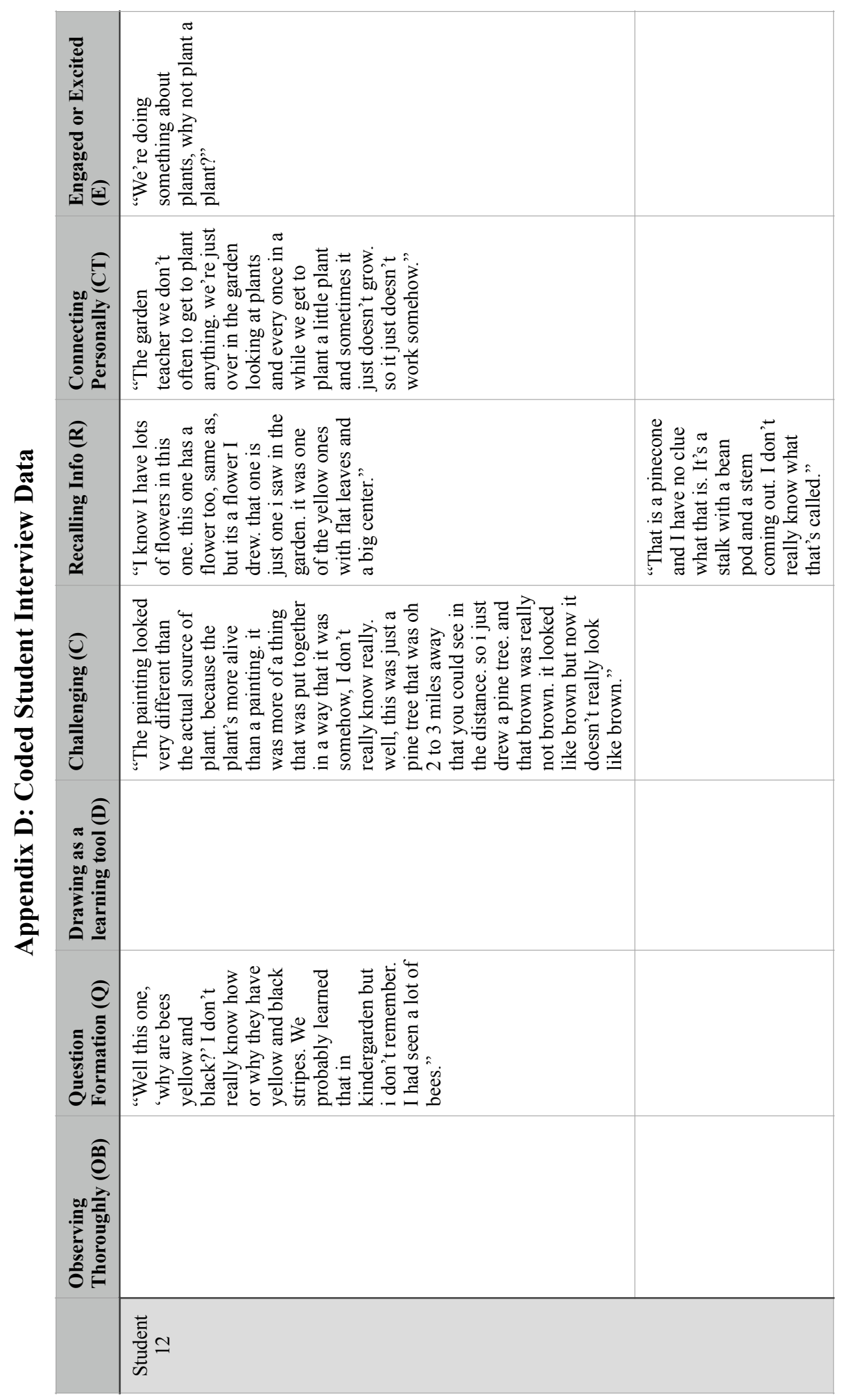




\begin{tabular}{|c|c|c|}
\hline 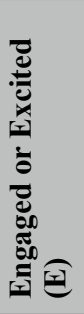 & 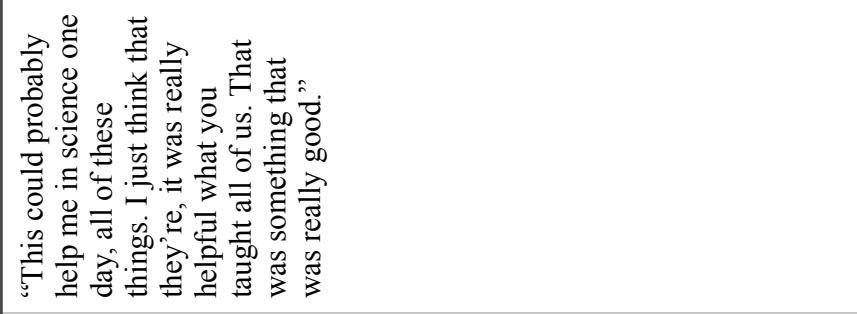 & 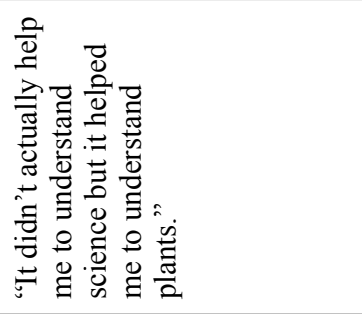 \\
\hline 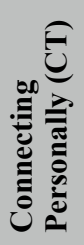 & & \\
\hline 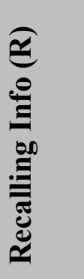 & 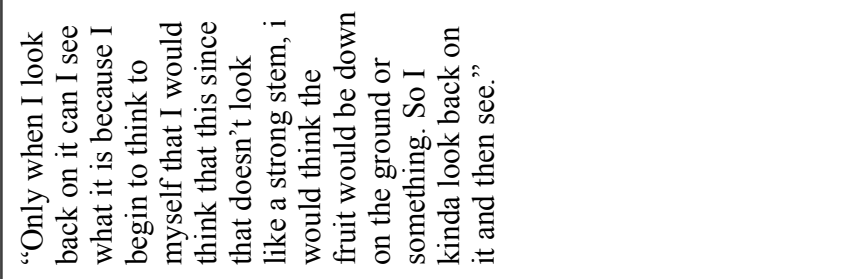 & 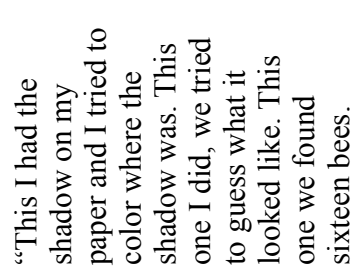 \\
\hline 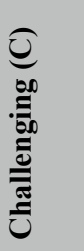 & & \\
\hline 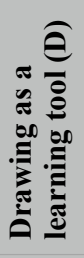 & 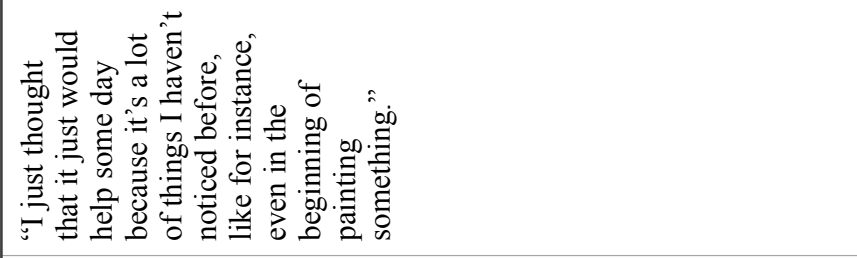 & \\
\hline 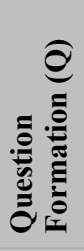 & 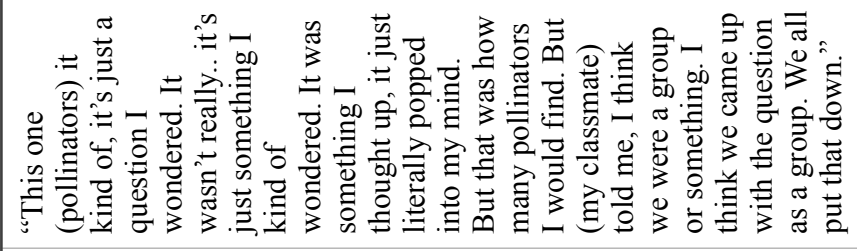 & 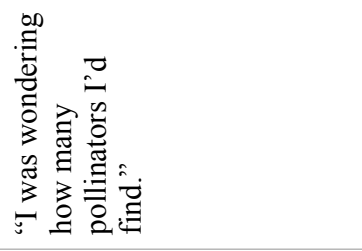 \\
\hline \multirow[t]{2}{*}{ 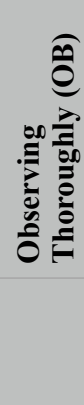 } & 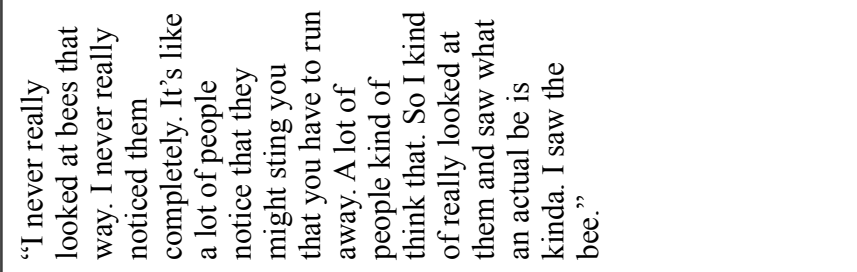 & 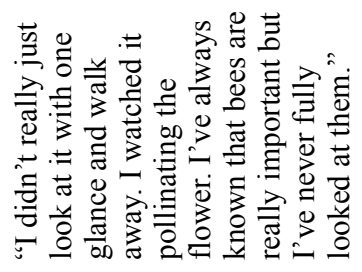 \\
\hline & \multicolumn{2}{|l|}{ 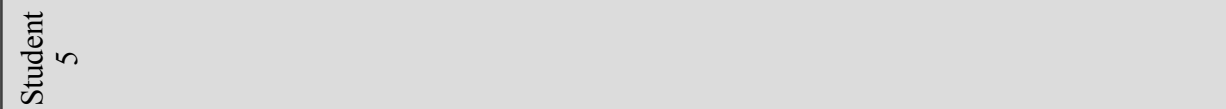 } \\
\hline
\end{tabular}




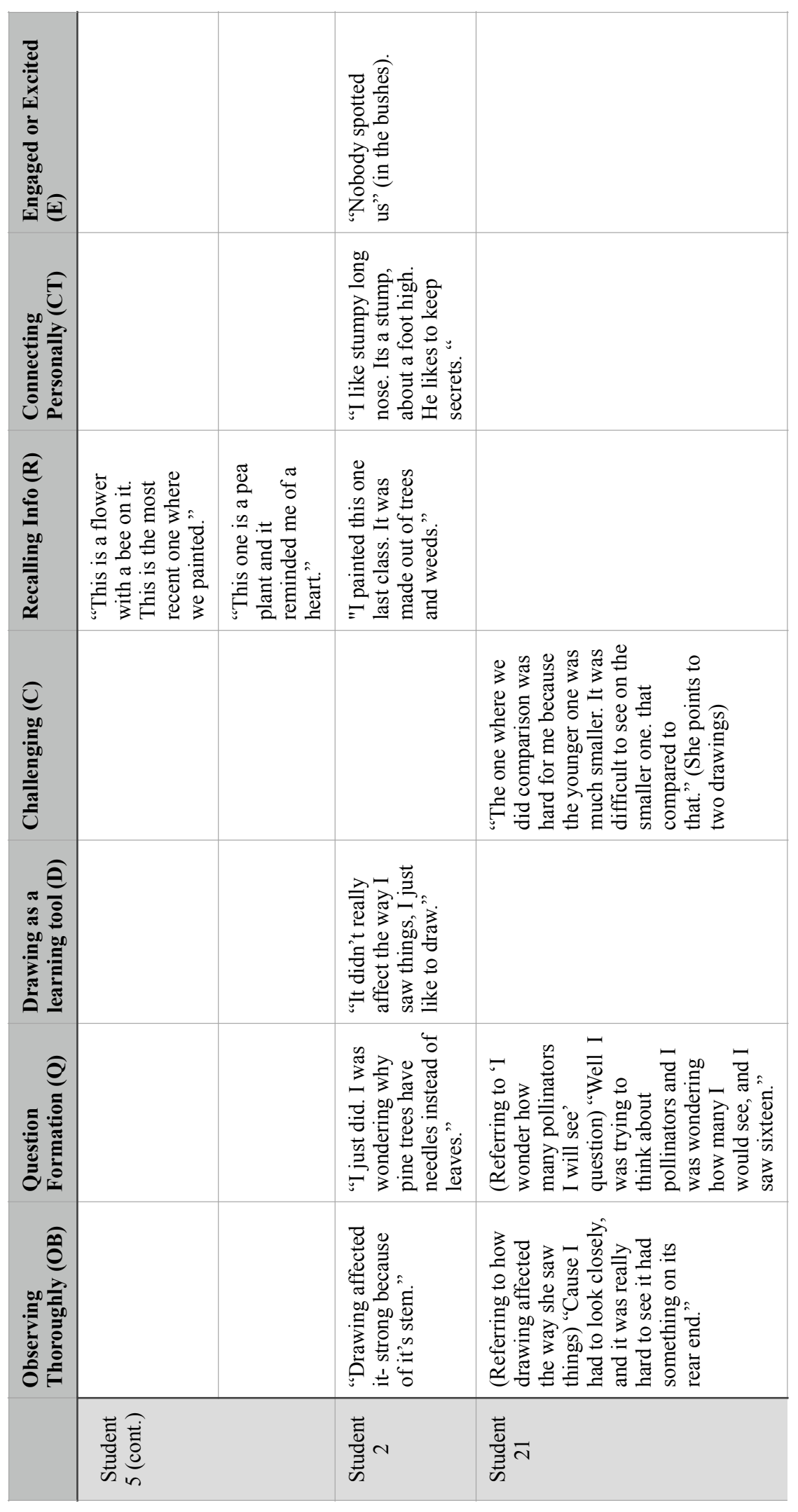




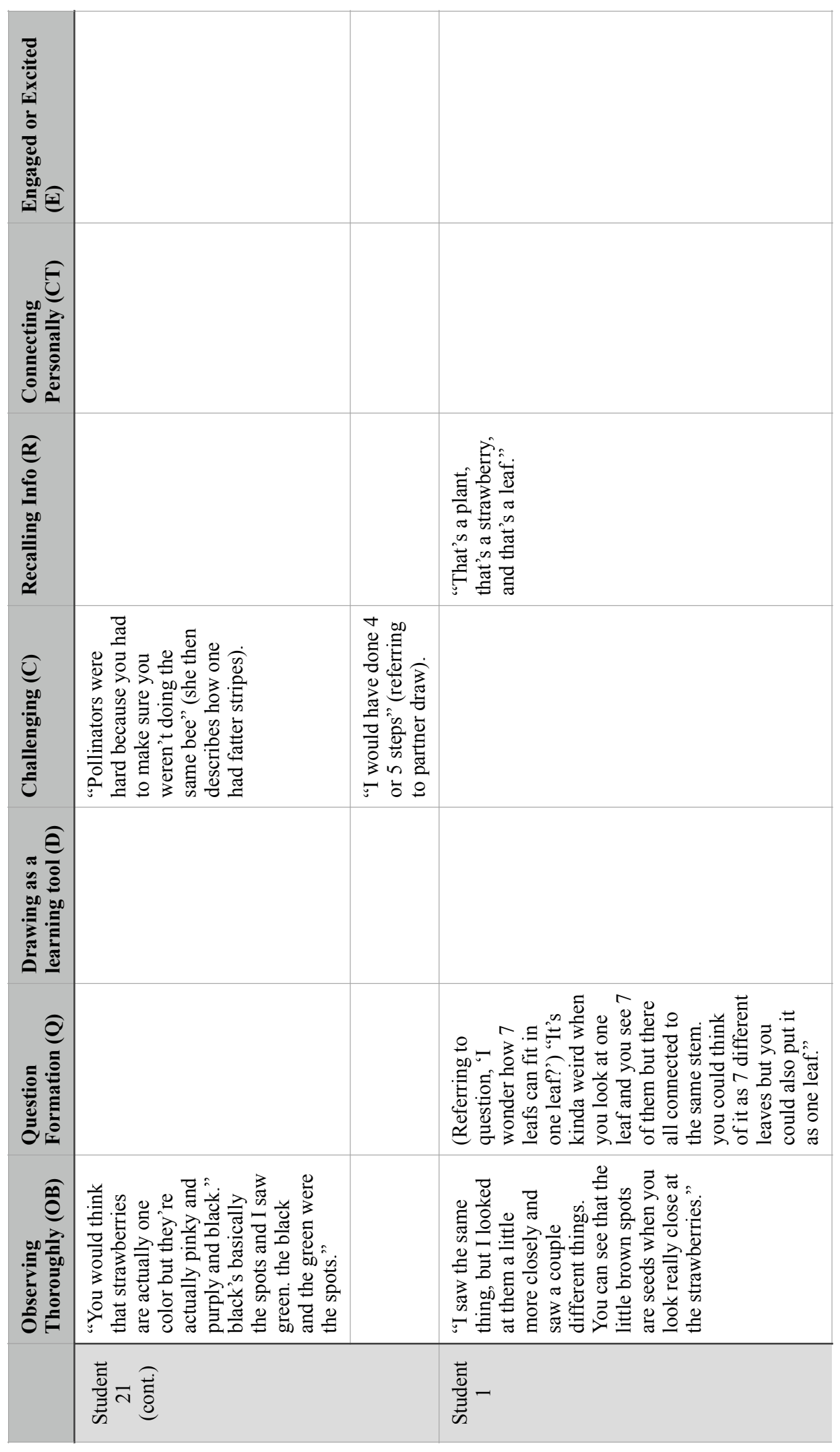




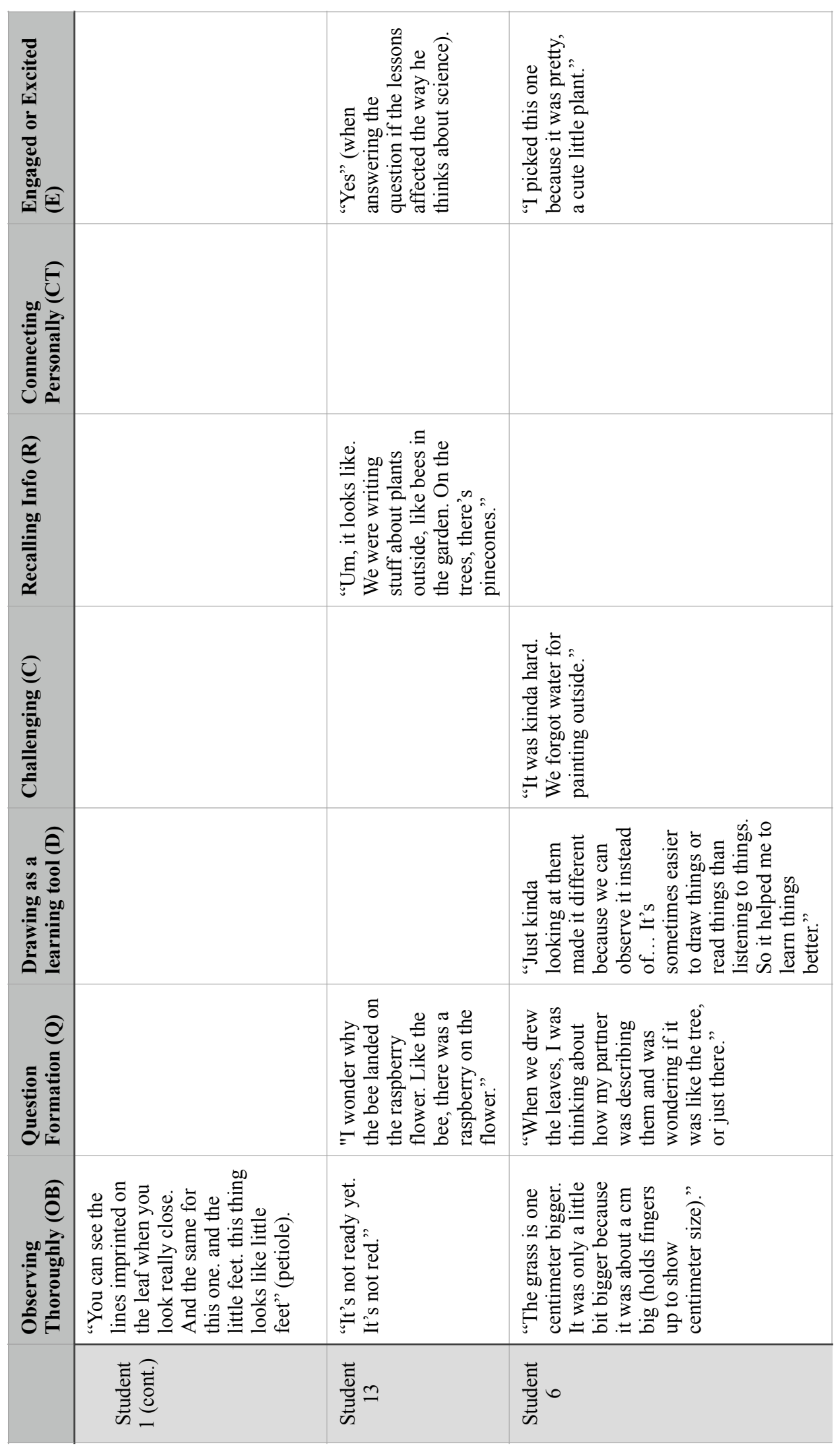




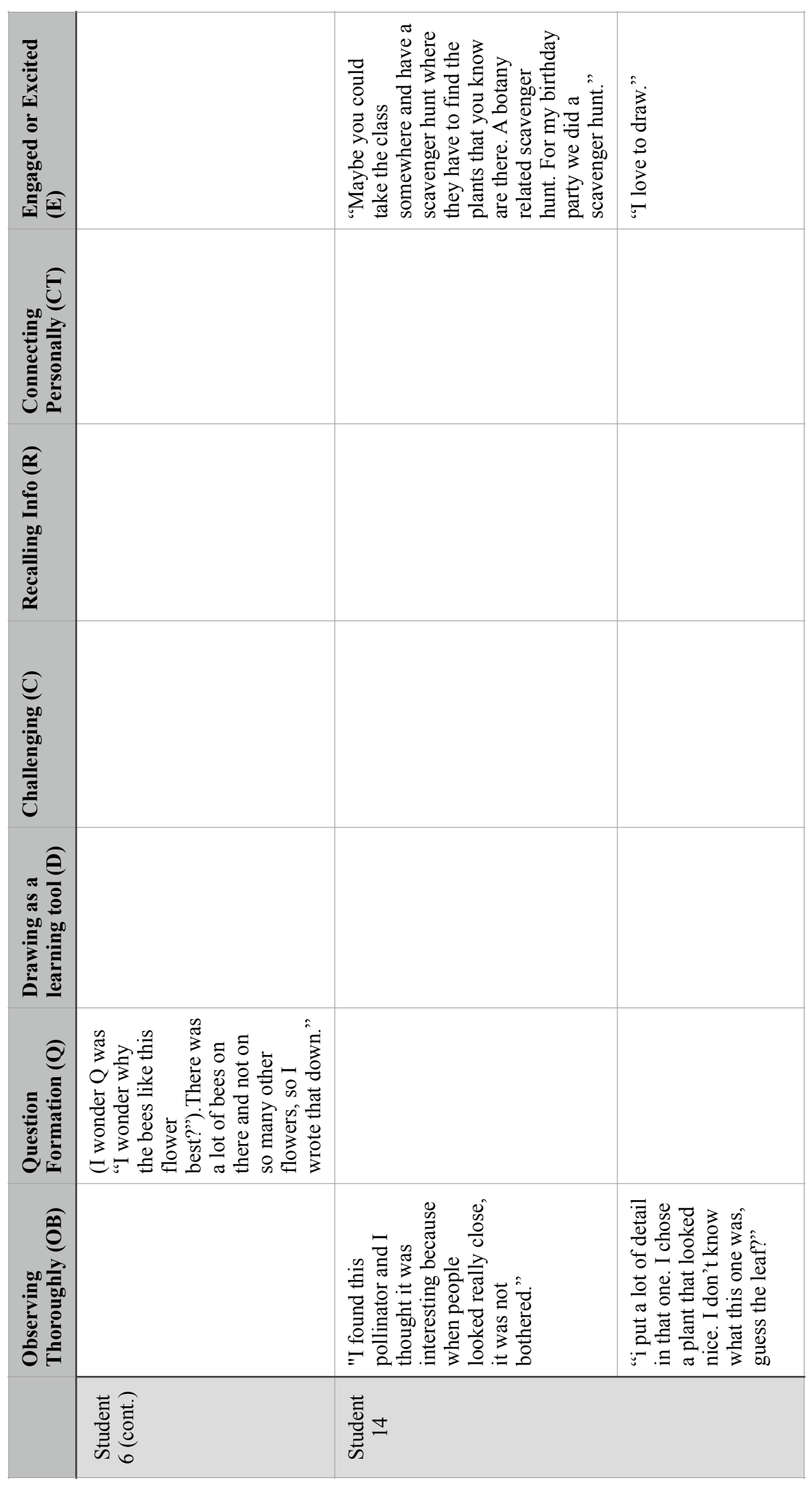




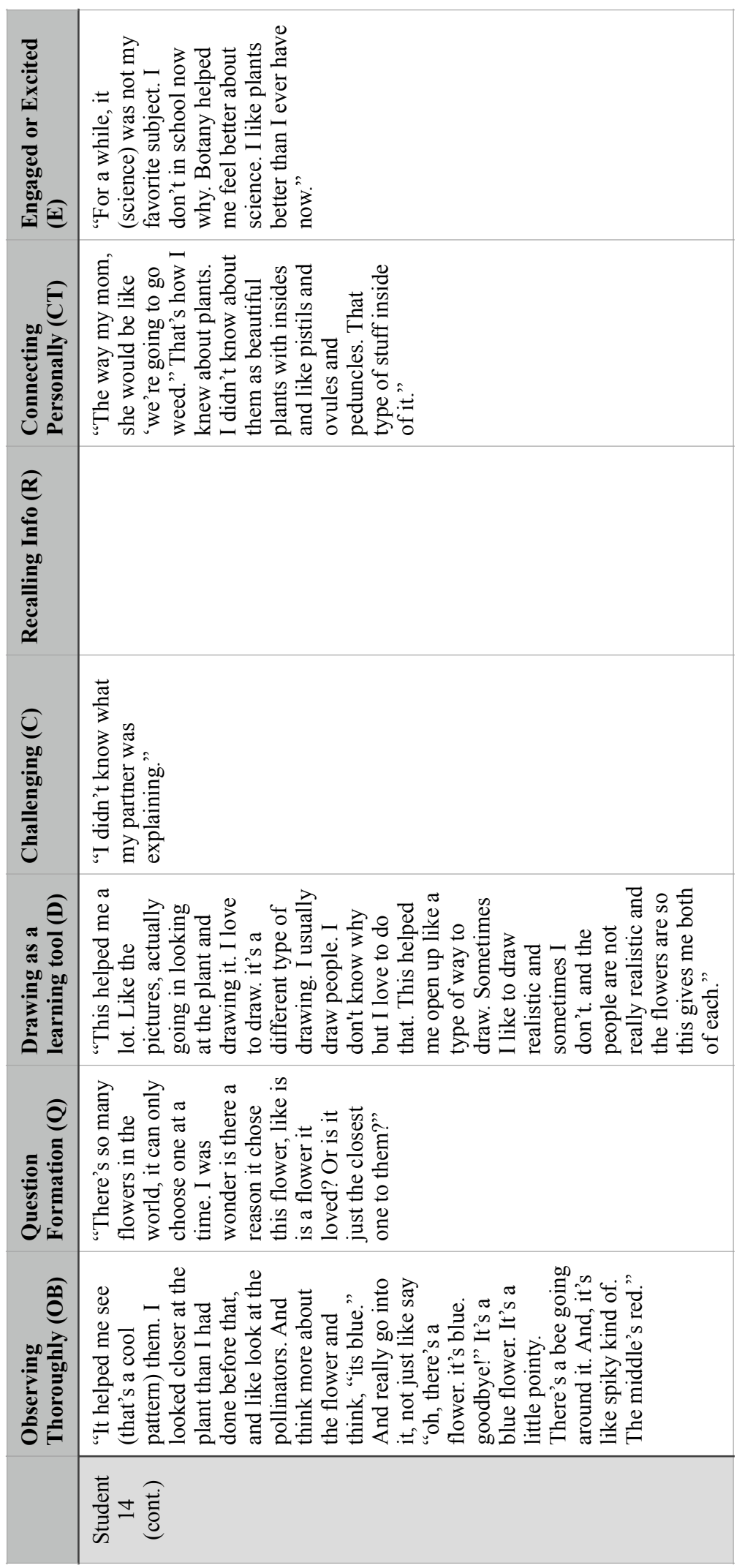




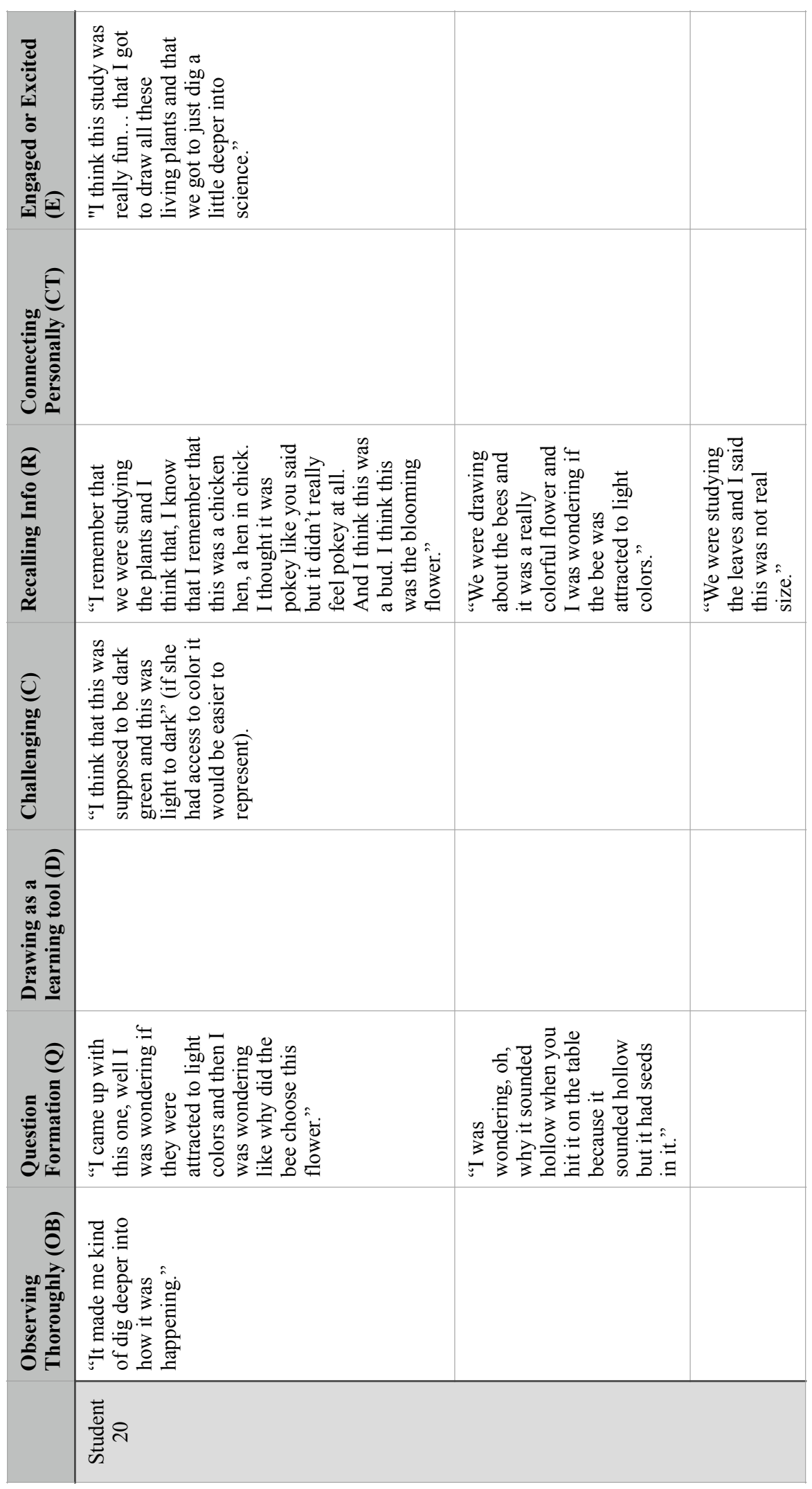

